\title{
Economic Contributions of the Dairy Farming and Dairy Product Manufacturing Industries in the Southeast United States in $2005^{1}$
}

Thomas J. Stevens, Alan W. Hodges, W. David Mulkey, and Richard L. Kilmer²

\section{Summary}

The objective of this analysis was to estimate the economic contributions of the dairy farm production and dairy product manufacturing industries in five southeastern states (Alabama, Florida, Georgia, South Carolina, and Tennessee) during 2005. Dairy farming in this region and the United States has seen significant structural changes in the 20 years between 1986 and 2005. Despite increased production per cow, total milk production in these five states declined by 20 percent during this period.

Florida and Georgia dominated production in the region, accounting for 46 and 25 percent, respectively, of the region's $\$ 904.3$ million (M) in dairy farm revenues for 2005. In 2005, the dairy product manufacturing sector generated revenues of $\$ 3.91$ billion (B). Sixty-four percent, or $\$ 2.5$ billion of these revenues went to the fluid milk processing subsector. The ice-cream and cheese manufacturing subsectors were a distant second (\$607 million) and third (\$386 million) in size, respectively. Among the five states, Tennessee and Florida had the highest levels of economic activity in dairy product manufacturing. Florida was the leading producer of fluid milk. Tennessee led the five states in the production of dry, condensed, and evaporated dairy products, while Alabama led the region in cheese manufacturing.

Since little data were available on the geographic origin of dairy farm and dairy product revenues to the region, estimation of the economic importance of these industries was evaluated from the standpoint of their contribution to their state's economy or the economic losses that would occur if they ceased to exist. To estimate the total economic contributions of these industries, input-output models for both dairy farming and dairy product manufacturing were constructed for each state using the IMPLAN input-output modeling software and databases. The production function used to represent the dairy farming industry in IMPLAN was customized to conform to budgets published by the USDA for the Southeast.

1. This is EDIS document FE731, a publication of the Food and Resource Economics Department, Florida Cooperative Extension Service, Institute of Food and Agricultural Sciences, University of Florida, Gainesville, FL. Published August 2008. Please visit the EDIS website at http://edis.ifas.ufl.edu.

2. Thomas J. Stevens, post doctoral associate; Alan W. Hodges, extension scientist; W. David Mulkey, professor; and Richard L. Kilmer, professor, Food and Resource Economics Department, Florida Cooperative Extension Service, Institute of Food and Agricultural Sciences, University of Florida, Gainesville, FL.

The Institute of Food and Agricultural Sciences (IFAS) is an Equal Opportunity Institution authorized to provide research, educational information and other services only to individuals and institutions that function with non-discrimination with respect to race, creed, color, religion, age, disability, sex, sexual orientation, marital status, national origin, political opinions or affiliations. U.S. Department of Agriculture, Cooperative Extension Service, University of Florida, IFAS, Florida A. \& M. University Cooperative Extension Program, and Boards of County Commissioners Cooperating. Larry Arrington, Dean 
The types of economic impacts or contributions estimated with the input-output models include output, value-added, labor income, other property income, indirect business taxes, and employment. These contributions can occur through direct, indirect, or induced effects. Direct effects are the revenues and jobs created directly by each industry. Indirect effects occur when dairy farms and product manufacturers purchase inputs from local suppliers. Induced effects occur when proprietors and employees spend earnings for personal consumption in their local economies. The total economic contributions of an event or activity equal the sum of these direct, indirect, and induced contributions.

The estimated total output contributions (revenues) of dairy farming for 2005 range from $\$ 65$ million for Alabama to $\$ 778$ million for Florida, and total $\$ 1.68$ billion for the five southeastern states combined. This represents a multiplier effect of approximately 1.86 times the $\$ 904$ million in direct dairy farm revenues for 2005 . The total value-added contributions (revenues minus the cost of intermediate inputs) of dairy farming for the five states are estimated to equal $\$ 653$ million. This value-added impact is composed of $\$ 486$ million in Labor Income, \$126 million in Other Property Income, and \$41 million in Indirect Business Taxes. Approximately 15,698 jobs were created as a result of dairy farms and their multiplier effects in the five southeastern states. This is nearly 2.1 times the number of jobs created directly by the industry.

The total output contribution of dairy products manufacturing for the Southeast region is estimated at $\$ 6.86$ billion. This is 1.75 times larger than the $\$ 3.91$ billion in revenues generated directly by the industry. Value-added contributions are estimated at \$2.14 billion, and are comprised of $\$ 1.35$ billion in Labor Income, $\$ 632$ million in Other Property Income, and $\$ 158$ million in Indirect Business Taxes. The total employment impacts generated by the dairy product manufacturing industries in 2005 for the five southeastern states are estimated at 33,383 jobs. This is 4.5 times the 7,412 jobs generated directly by this industry that year.

The combined total output contribution of both dairy farming and dairy products manufacturing industries in 2005 for the five states was estimated to be $\$ 8.54$ billion. As was true for revenues, Florida and Tennessee generated significantly larger contributions than the other states in 2005, with an estimated $\$ 2.94$ billion and $\$ 2.82$ billion in output contributions, respectively. Combined value-added contributions from dairy farming and processing in the five states were estimated to total $\$ 2.80$ billion for 2005. This value-added figure was comprised of $\$ 1.84$ billion in Labor Income, $\$ 758$ million in Other Property Income, and \$198 million in Indirect Business Taxes paid to local, state, and federal governments. Florida showed the largest value-added contributions from dairy farming and processing in 2005 at $\$ 1.02$ billion, followed closely by Tennessee with $\$ 927$ million. The combined total number of jobs contributed by these industries for the five states was estimated to be 49,081. Again, Florida and Tennessee experienced significantly larger job contributions than the other three states, with 17,450 and 16,217 jobs respectively.

In relative terms, the combined dairy industries are more important to the states of Tennessee, Alabama, and Florida, representing 0.41, 0.20, and 0.15 percent of the gross state product of each state, respectively, in 2005. As previously mentioned, dairy industry activity in Florida and Tennessee leads the region in absolute terms. These two states capture nearly 70 percent of the industry's total contribution to the region. Overall, the dairy product manufacturing subsectors contributed more than three times as much to the combined economies of the five southeastern states as did dairy farming in and of itself.

\section{Acknowledgment}

This study was carried out under the sponsorship of Southeast Milk, Inc. of Belleview, Florida, a dairy marketing cooperative that distributes raw and processed milk products in Florida and other states in the Southeast United States.

\section{Introduction}

The dairy industry continues to evolve in the United States for a variety of reasons. These include consolidation and regional shifts in production and processing, changes in consumer demand for dairy 
products as a result of shifting demographics and dietary habits, and increasingly competitive pressures from other food and beverage industries. These trends have contributed to interest in evaluating the regional economic impacts or contributions of the dairy industry for individual states, regions, and the nation as a whole (Cryan 2004; Deller 2007).

The objective of this analysis was to estimate the economic contributions of dairy farm production and dairy product manufacturing in five southeastern states, including Alabama, Florida, Georgia, South Carolina, and Tennessee, for the year 2005. This study represents a comprehensive assessment of the regional economic activity associated with dairy farms and dairy product manufacturers, including the secondary or "multiplier" effects associated with inputs purchased from other local businesses and employee household spending, in addition to industry sales and employment. This analysis enables an assessment of the industry's relative importance to the region's overall economy and other sectors within the economy.

\section{Industry and Study Area Description}

\section{Dairy Farm Sector}

Since 1990, there have been significant structural and regional shifts in dairy production within the United States. Generally, production has increased in the Pacific and Mountain states, and decreased in the Northeast, Lake states, Corn-belt states, and the South (Figure 1). There has also been substantial consolidation in the industry throughout the nation, with average herd size increasing and the number of farms decreasing.

Dairy farming in the Southeast has also seen significant structural changes during the last 20 years. In 2004, the average dairy farm in the Southeast had nearly three times as many cows as it did in 1986, but during the same period of time the number of farms declined by three-fourths (Figure 2). Although milk production per cow increased significantly during this period, total annual milk production for the Southeast decreased by over 20 percent from 6.7 to 5.2 billion pounds.

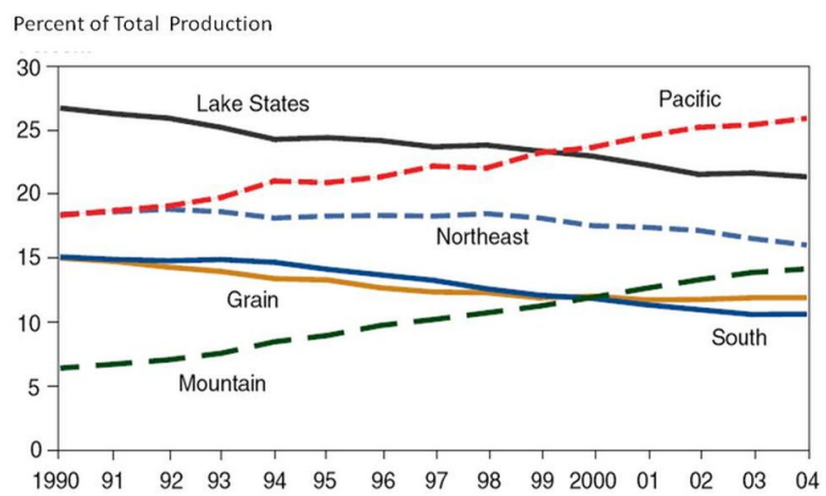

Figure 1. Regional milk production shares, 1990-2004. Source: USDA-ERS, Dairy Backgrounder (Figure 6), James J. Miller and Don P. Blayney, LDP-M-145-01, July 2006.

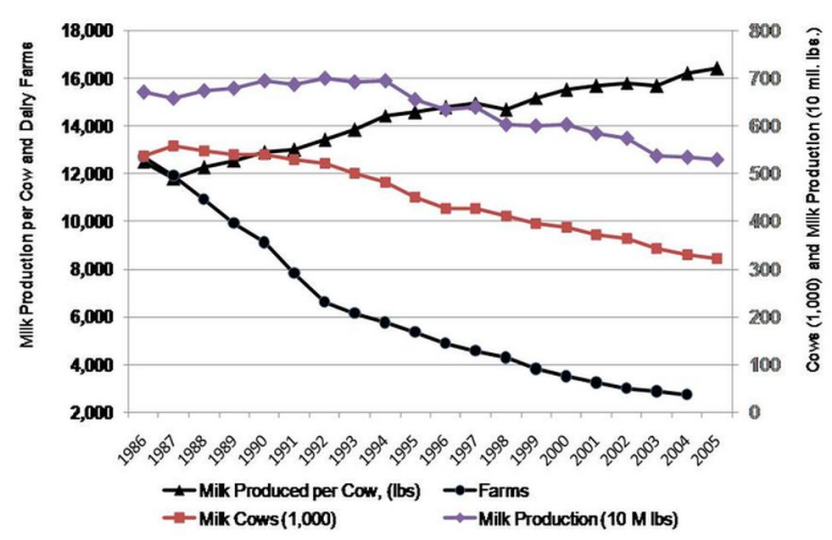

Figure 2. Dairy farm numbers, milk production per cow, herd size, and milk production for five southeastern states, 1986-2005. Source: USDA-NASS, Quick Stats (Agricultural Data and Statistics) http://www.nass.usda.gov/Data_and_Statistics/ Quick_Stats/index.asp.

Receipts and employment for dairy farms in five southeastern states for 2005 are shown in Tables 1 and 2. In absolute terms, dairy farming is larger in Florida, Georgia, and Tennessee as compared to Alabama and South Carolina. In 2005, Florida dairy farms generated over $\$ 421$ million in revenues and employed over 2,000 people as hired labor, not including owners or unpaid family members. Dairy farms were responsible for 5.4 percent of Florida's total agricultural receipts in 2005, and 2.8 percent of agricultural employment. Relative to the other southeastern states, dairy farming in Florida represented a larger percentage of the state's total jobs ( 0.026 percent) than the other four states in the study. At seven percent, the share of total farm receipts contributed by dairy farming in Tennessee 
was the largest among the five states. However, employment by dairy farms in Tennessee represented less than 0.02 percent of the state's total jobs.

\section{U.S. Bureau of Labor Statistics data for} employment by dairy farms only counts hired labor, not owners and family members. Since a substantial number of individuals who actively work on dairy farms are operators or operator family members, it was necessary to consolidate data from the U.S. Agricultural Census and Bureau of Labor Statistics (BLS) to accurately estimate total employment (Table 2). It is estimated that 7,556 individuals were employed or self-employed on dairy farms within the five states in 2005. Florida accounted for over 38 percent $(2,893)$ of these jobs. Dairy farms in Tennessee and Georgia employed or self-employed 1,906 and 1,745 individuals, respectively. In 2005, output or revenues generated per employee on dairy farms in each state ranged from $\$ 145,688$ for Florida to $\$ 76,162$ for Alabama (Table 2).

\section{Dairy Products Manufacturing Sector}

The dairy processing or dairy product manufacturing industry consists of five subsectors: fluid milk; creamery butter; cheese; dry, condensed, and evaporated milk; and ice-cream and frozen dessert manufacturing. Not all of these subsectors exist in each of the five states, and in some states there are so few establishments that government statistics cannot be published under confidentiality requirements. As a result, some dairy product manufacturing data had to be estimated. Details on this process are discussed in the Methods section of this report.

Published and estimated data for the dairy product manufacturing sectors in five southeastern states are presented in Table 3. For these states, there were 107 establishments in 2005, which generated an estimated $\$ 3.9$ billion in revenues, employed 7,412 workers, and paid those workers over \$296 million in wages that year. Among the five states, Tennessee and Florida had the greatest levels of activity in this sector. Although Florida had about 50 percent more establishments than Tennessee, output (revenues), wages paid, and employment numbers for the two states were very close. Fluid milk dominates the dairy product manufacturing sector in these states, with ice-cream and cheese following a distant second and third in size, respectively. Tennessee leads the five states in the production of dry, condensed, and evaporated dairy products, while Alabama and Florida lead the region in cheese manufacturing.

\section{Methods}

To carry out a standard economic impact analysis, accurate data are not only required on the revenues, expenditures, or employment associated with the industry or event under consideration, but also on the geographic location or origin of these dollars and jobs. When nonlocal or "new" dollars flow into a regional economy through revenues generated by sales to buyers outside the region, additional multiplier effects occur as directly impacted businesses purchase inputs from local suppliers, as the households of employees and proprietors of these businesses spend earnings, and as local governments collect and spend taxes.

In the case of sales of raw milk and processed dairy products produced in the Southeast, little data were available on the geographic location of the wholesale buyers of these products (i.e., shipments across state lines), but the consensus of expert opinion was that most dairy products produced in the south were consumed within the region. To evaluate the economic importance of an industry in this case properly, it was necessary to reframe the context of the analysis. Since milk and most milk products can be considered a necessity for human nutrition and health (with a small elasticity of demand), if the dairy farming and dairy product manufacturing industries in the Southeast were to disappear, their products would have to be imported from other regions of the country to replace them. If that were to occur, then the dollars used to purchase these nonlocal products would leave the regional economy of the Southeast, and reduce spending, revenues, and jobs for the region. When the economic importance of an industry or activity is evaluated under these assumptions, it is more appropriate to refer to the estimated economic impacts as economic contributions (Watson, Wilson, Thilmany, and Winter 2007).

When the importance of an industry or activity is evaluated on the basis of how much of a loss to the 
economy would occur if it no longer existed, the input-output model used to estimate this value must be modified so that all demands for the industry's products within the region are supplied or replaced by imports from outside the region. This can be handled in the model by setting the regional purchase coefficients for these commodities or industries to zero (Steinback 2004).

To proceed with the estimation of the economic contribution of the dairy industry in the five-state region, input-output models were first constructed for each state using the IMPLAN economic impact modeling system (Minnesota IMPLAN Group). The IMPLAN data set used for this analysis was for the year 2003. IMPLAN includes computational software for building economic models and calculating impacts, as well as economic databases that support regional model construction for individual counties or states or groups of counties or states. Economic models built using IMPLAN can be customized in a variety of ways to incorporate more detailed or up-to-date data, and to accommodate a variety of different modeling assumptions, depending on the objectives and nature of the analysis.

Several other modifications to the IMPLAN model were also necessary. First, the current industry sector scheme used in IMPLAN combines dairy farming with all other types of cattle farming and ranching (sector 11). To make the IMPLAN model more representative of dairy farming in the Southeast, the production function for IMPLAN sector 11 was modified to conform with dairy production budgets published by the USDA Economic Research Service (USDA-ERS) for Florida, Georgia, and Tennessee. The dairy farm production budget used to make these modifications is shown in Table 4. In some cases, there was not a one-to-one correspondence between USDA budget items and the IMPLAN sector scheme. In these cases, individual budget items were allocated to multiple IMPLAN sectors as shown in the fifth column of Table 4.

IMPLAN economic data on dairy farm and dairy product manufacturing activity in each of the five states were also updated with more recent statistics published by the USDA and the U.S. Department of Commerce, Bureau of Labor Statistics, for 2005. For several states, there were not enough dairy product manufacturers to permit publication of industry statistics. Thus it was necessary to estimate these missing statistics by using more aggregate or national industry averages or ratios, such as revenues and employees per establishment, or revenues per employee. These estimates were then adjusted so that the sum of subsector values equaled published aggregate dairy product manufacturing statistics. State level data/estimates for receipts, employment, wages, and other components of value-added expenditures for each of these subsectors were updated as shown in Table 3.

Two input-output models were then constructed for each of the five states. The first set of models was used to estimate the economic contributions of dairy farming alone. These models did not incorporate any changes to the dairy product manufacturing subsectors. Because dairy farms use products from the animal food manufacturing sector (which in turn uses products from the dairy product manufacturing sector), changing the characteristics or activities of the dairy product manufacturers in the input-output models affects the estimated economic contributions of the dairy farm sector. The second set of models was specified to estimate the economic contributions of both dairy farming and dairy product manufacturing industries for each state. Economic contributions generated by the dairy product manufacturing sector alone were estimated by subtracting estimated dairy farm contributions from the estimated combined contributions of both farms and manufacturers.

The types of economic impacts or contributions estimated with the input-output models include output, value-added, labor income, other property income, indirect business taxes, and employment (see glossary in Table 7 for definitions). These contributions can occur through direct, indirect, or induced effects. Total economic contributions of an event or activity equal the sum of these direct, indirect, and induced contributions. Output contributions represent the total value of revenues or expenditures associated with an activity. Value-added measures the labor income, property income, and indirect business taxes generated from these revenues. Labor income represents earnings by 
employees and proprietors of impacted businesses. Other property types of income represent corporate profits in addition to payments for rents, royalties, dividends, and interest. Indirect business taxes include excise, property, and sales taxes, as well as licenses and fees paid by businesses, but not taxes on profits or income. The estimated number of annual full-time, part-time, and seasonal jobs resulting from industry activity is represented by employment. Each of these measures represents a different way of assessing the size or contribution of an economic activity on a region.

\section{Results}

Summary economic contributions estimated for dairy farming and dairy product manufacturing individually, and the two industries combined in the Southeast United States for 2005 are shown in Table 5. Estimated contributions for each state are shown in individual rows, and the different types of economic contributions are arranged by table columns. Units are in millions of 2005 U.S. dollars, or in jobs representing all employment, including full-time, part-time, seasonal, and self-employed.

The estimated output contributions of dairy farming for 2005 are shown to range from $\$ 65$ million for Alabama to $\$ 778$ million for Florida, and total $\$ 1.68$ billion for the five southeastern states combined. Since an estimated \$904 million in combined revenues (Table 1) generated these combined output contributions, this represents a multiplier effect of approximately 1.86. The total value-added contributions of dairy farming for the five states are estimated to equal $\$ 653$ million. This value-added impact was composed of $\$ 486$ million in Labor Income, \$126 million in Other Property Income, and \$41 million in Indirect Business Taxes. An estimated 15,698 jobs were created as a result of dairy farms and their multiplier effects in the five southeastern states. This is over two (2.07) times the 7,556 jobs directly involved in dairy farming (Table 2).

The total output contribution of dairy products manufacturing for the Southeast region is estimated at $\$ 6.86$ billion (Table 5). This is 1.75 times larger than the $\$ 3.91$ billion in revenues generated directly by the industry (Table 3). Value-added contributions are estimated at $\$ 2.14$ billion, and are comprised of $\$ 1.35$ billion in Labor Income, $\$ 632$ million in Other Property Income, and $\$ 158$ million in Indirect Business Taxes. The total employment impacts generated by the dairy product manufacturing industries in 2005 for the five southeastern states are estimated at 33,383 jobs. This is 4.5 times the 7,412 jobs generated directly by this industry that year (Table 3).

The estimated output contribution of the dairy farming and dairy products manufacturing industries in 2005 for the five states was estimated to total $\$ 8.54$ billion (Table 5). As was true for revenues, Florida and Tennessee generated significantly larger contributions than the other states in 2005, with an estimated $\$ 2.94$ billion and $\$ 2.82$ billion in output contributions, respectively. Combined value-added contributions from dairy farming and processing in the five states were estimated to total $\$ 2.80$ billion for 2005. This value-added figure was comprised of $\$ 1.84$ billion in Labor Income, $\$ 758$ million in Other Property Income, and $\$ 198$ million in Indirect Business Taxes paid to local, state, and federal governments. Florida showed the largest value-added contributions from dairy farming and dairy product manufacturing in 2005 at $\$ 1.02$ billion, followed closely by Tennessee with $\$ 927$ million. The combined total number of jobs generated by these industries for the five states was estimated to be 49,081. Again, Florida and Tennessee experienced significantly larger job contributions than the other three states, with 17,450 and 16,217 jobs, respectively.

Detailed economic contributions by two-digit NAICS sectors are provided in Table 8 of this report for dairy farming, dairy product manufacturing, and dairy farming and dairy product manufacturing combined, respectively. For dairy farm production, the top three two-digit NAICS sectors being affected are Agriculture, Manufacturing, and Government (Table B-1). This ranking was consistent across the five states. For value-added, the top sectors were Agriculture, Government, and Wholesale Trade (Table 9). In terms of employment contributions from dairy farming, the largest contribution effects 
occurred in Agriculture, Government, and Retail Trade (Table 10).

For dairy product manufacturing, Manufacturing, Government, and Wholesale Trade experienced the largest output contributions (Table 11). The same sectors also had the greatest economic contributions in terms of value-added (Table 12). For employment, Manufacturing, Government, and Retail Trade had the greatest contributions from dairy product manufacturing (Table 13).

For dairy farming and dairy product manufacturing combined, the sectors having the greatest output contributions across the five states were Manufacturing, Agriculture, and Government (Table 14). This could be expected since dairy product manufacturing is included in the aggregate manufacturing sector. The order of industries showing the largest value-added contributions was similar to output, with Manufacturing coming first, Government second, and Agriculture third (Table 15). In terms of jobs, Agriculture saw the greatest contributions, followed by Manufacturing and Government (Table 16).

\section{Discussion}

Generating an estimated $\$ 8.5$ billion in total economic output contributions, $\$ 2.8$ billion in value-added and 49,000 jobs in 2005, the dairy farming and dairy product manufacturing industries combined are a significant component to the economy of the Southeast United States. In relative terms, these industries are more important to the states of Alabama, Florida, and Tennessee, and less so for Georgia and South Carolina (Table 6). Dairy industry activity in Florida and Tennessee leads the region, with value-added contributions in 2005 of $\$ 1.02$ billion and $\$ 927$ million, respectively. This represents nearly 70 percent of the industry's total contribution to the region. Overall, dairy product manufacturing contributed more than three times as much to the combined economies of the five southeastern states as did dairy farming.

Comparing these results with numbers published by Cryan for the years 1998 through 2003, the magnitudes of the estimates for output and employment from this analysis are generally smaller.
This is likely due to the general decline in dairy farm production in the region since the 1990s. Otherwise, the relative proportions of impacts or contributions among the states are generally comparable.

The following caveats should be kept in mind when considering the results of this study. This analysis only evaluates the positive economic impacts or contributions in terms of revenues, income, taxes, or jobs, resulting from business activities associated with dairy farming and dairy product manufacturing in the Southeast United States. It does not account for any costs, direct or indirect, to the government or surrounding community that may result from it. It should be kept in mind that this study differs from a standard impact analysis that focuses on sales of products outside the region. Rather, this study is based on the assumption that most dairy products are consumed within the region and would be replaced by imports if regional production were unavailable. Possible effects on regional prices for goods, services, or real estate are not evaluated. Estimates of the secondary (indirect and induced) contributions calculated by the economic models used in this analysis are largely based on national averages. Thus their accuracy rests on the assumption that the economic relationships between businesses and institutions in the study area are similar to those of the United States as a whole.

\section{References}

Cryan, Roger. 2004. The economic impact of the dairy industry. U.S. Dairy Markets and Outlook, Dairy Management 10(1). http://future.aae.wisc.edu/publications/ $\underline{\text { US_Outlook_May_2004.pdf }}$

Deller, Steven C. 2007. The economic impact of milk production on the Wisconsin economy. Staff Paper Series No. 506, University of Wisconsin, Department of Agricultural and Applied Economics, Madison, Wisconsin. http://ageconsearch.umn.edu/handle/123456789/ $\underline{26105}$

Giesy, R. L. Ely, B. Broaddus, C. Vann, A. Bell, and A. De Vries. 2007. Dairy business analysis project: 2005 financial summary. Electronic Data Information Source (EDIS) AN179, Department of 
Animal Sciences, University of Florida, Gainesville, FL (February). http://edis.ifas.ufl.edu/AN179

Miller, James J. and Don P. Blayney. 2006. Dairy backgrounder. Outlook Report LDP-M-145-01, National Agricultural Statistics Services, United States Department of Agriculture, Washington, D.C. (July).

http://www.ers.usda.gov/Publications/LDP/2006/ $\underline{07 \mathrm{Jul} / \mathrm{LDPM} 14501 /}$

Minnesota IMPLAN Group (MIG), 2004. IMPLAN Pro, Economic Impact and Social Accounting Software, and Data, Stillwater, MN. http://www.implan.com

Pavlaskik, Steve. 2005. Personal Communication, (803) 765-5333. South Carolina Field Office, National Agricultural Statistics Service, United States Department of Agriculture, Washington, D.C.

South Carolina Agricultural Statistics Service. 2005. Revised SCASS Report. Department of Applied Economics \& Statistics, Clemson University, Clemson, SC. http://cherokee.agecon.clemson.edu/cash_rec.pdf

Steinback, Scott. 2004. Using ready-made regional input-output models to estimate backward-linkage effects of exogenous output shocks. Review of Regional Studies 34(1): 57-71. http://www.economy.okstate.edu/rrs/ issue.asp? volume $=34 \&$ issue $=1$

Tennessee Department of Agriculture. 2007. Tennessee Agriculture 2007. Annual Report, Tennessee Department of Agriculture, Nashville, TN. http://www.tennessee.gov/agriculture/annualreport/

U.S. Dept. of Commerce, BLS. Quarterly census of employment and wages. Bureau of Labor Statistics, U.S. Department of Commerce, Washington, D.C. http://data.bls.gov/PDQ/outside.jsp?survey=en

USDA-ERS. 2007. Milk production costs and returns from the 2005 agricultural resource management survey. Economic Research Service, United States Department of Agriculture, Washington, D.C.
http://www.ers.usda.gov/Data/CostsAndReturns/ $\underline{\text { MilkAll.xls }}$

USDA-NASS. 2002 Census of Agriculture, Volume 1, State Level Data. National Agricultural Statistics Service, United States Department of Agriculture, Washington, D.C.

http://www.nass.usda.gov/census/census02/volume1/ al/st01_1_059_059.pdf

USDA-NASS. Annual statistical bulletins for Alabama, Florida and Georgia, 2005/2006. National Agricultural Statistics Service, United States Department of Agriculture, Washington, D.C. http://www.nass.usda.gov/Statistics_by_State/ Alabama/Publications/Annual_Statistical_Bulletin/ pg45.pdf

http://www.nass.usda.gov/Statistics_by_State/Florida/ Publications/Economics/fcrexp06.pdf

http://www.nass.usda.gov/Statistics_by_State/ Georgia/Publications/Annual_Statistical_Bulletin/ 2006/2006CashReceipts.pdf

USDA-NASS. 2005. Dairy yearbook: operations with milk cows, by state and region. National Agricultural Statistics Service, United States Department of Agriculture, Washington, D.C. (September). http://usda.mannlib.cornell.edu/MannUsda/ viewDocumentInfo.do?documentID=1207

Watson, Philip, Joshua Wilson, Dawn Thilmany, and Susan Winter. 2007. Determining economic contributions and impacts: what is the difference and why do we care? Journal of Regional Analysis and Policy 37(2): 140-146. http://www.jrap-journal.org/pastvolumes/2000/v37/ F37-2-6.pdf 
Table 1. Dairy farm receipts for five southeastern states, 2005.

\begin{tabular}{|c|c|c|c|}
\hline State & $\begin{array}{l}2005 \text { Dairy Farm } \\
\text { Receipts }\end{array}$ & $\begin{array}{l}\text { Share of State } \\
\text { Agriculture }\end{array}$ & $\begin{array}{c}\text { Change in Dairy } \\
\text { Receipts, 2004-2005 }\end{array}$ \\
\hline & (\$million) & $(\%)$ & (\% Change) \\
\hline Alabama & 37.7 & 0.8 & -13.3 \\
\hline Florida & 421.5 & 5.4 & -2.3 \\
\hline Georgia & 221.8 & 3.3 & -5.8 \\
\hline South Carolina & 47.6 & 2.3 & -3.6 \\
\hline Tennessee & 175.7 & 7.0 & -9.1 \\
\hline Total Average & 904.3 & 4.0 & -5.2 \\
\hline \multicolumn{4}{|c|}{$\begin{array}{l}\text { Sources: USDA-NASS, Quick Stats, Alabama, Florida, Georgia, South Carolina, and Tennessee. } \\
\text { http://www.nass.usda.gov/QuickStats/ } \\
\text { USDA-NASS, South Carolina Field Office, Personal Communication with Steve Pavlaskik, (803) } \\
\text { 765-5333. Tennessee Department of Agriculture, Tennessee Agriculture 2007, } \\
\text { http://www.tennessee.gov/agriculture/annualreport/ }\end{array}$} \\
\hline
\end{tabular}

Table 2. Dairy farm workforce for five southeastern states.

\begin{tabular}{|c|c|c|c|c|c|c|}
\hline State & $\begin{array}{l}\text { Dairy Operators } \\
2002(1)\end{array}$ & $\begin{array}{l}\text { Hired Labor } \\
2005 \text { (2) }\end{array}$ & $\begin{array}{c}\text { Combined } \\
\text { Operators \& } \\
\text { Hired (3) }\end{array}$ & $\begin{array}{c}\text { Output per } \\
\text { Worker }\end{array}$ & $\begin{array}{l}\text { Employment } \\
\text { Share of } \\
\text { Agriculture }\end{array}$ & $\begin{array}{c}\text { Employment } \\
\text { Share of } \\
\text { State Total }\end{array}$ \\
\hline & Workers & Workers & Workers & (\$) & (\%) & (\%) \\
\hline Alabama & 345 & 150 & 495 & $\$ 76,162$ & 2.8 & 0.0079 \\
\hline Florida & 884 & 2,009 & 2,893 & $\$ 145,688$ & 2.8 & 0.0259 \\
\hline Georgia & 794 & 951 & 1,745 & $\$ 127,083$ & 8.2 & 0.0242 \\
\hline South Carolina & 361 & 156 & 517 & $\$ 92,151$ & 3.0 & 0.0086 \\
\hline Tennessee & 1,589 & 317 & 1,906 & $\$ 92,172$ & 7.8 & 0.0118 \\
\hline Total Average & 3,973 & 3,583 & 7,556 & $\$ 119,674$ & 3.6 & 0.0198 \\
\hline \multicolumn{7}{|c|}{$\begin{array}{l}\text { 1. USDA-NASS, } 2002 \text { Census of Agriculture, } \\
\text { http://www.nass.usda.gov/census/census02/volume1/al/st01_1_059_059.pdf } \\
\text { 2. U.S. Department of Commerce, Bureau of Labor Statistics, Quarterly Census of Employment and Wages, } \\
\text { http://data.bls.gov/PDQ/outside.jsp?survey=en } \\
\text { 3. Combined employment estimated by adding dairy operators reported in } 2002 \text { U.S. Agricultural Census to hired dairy } \\
\text { workers reported in } 2005 \text { BLS data. }\end{array}$} \\
\hline
\end{tabular}




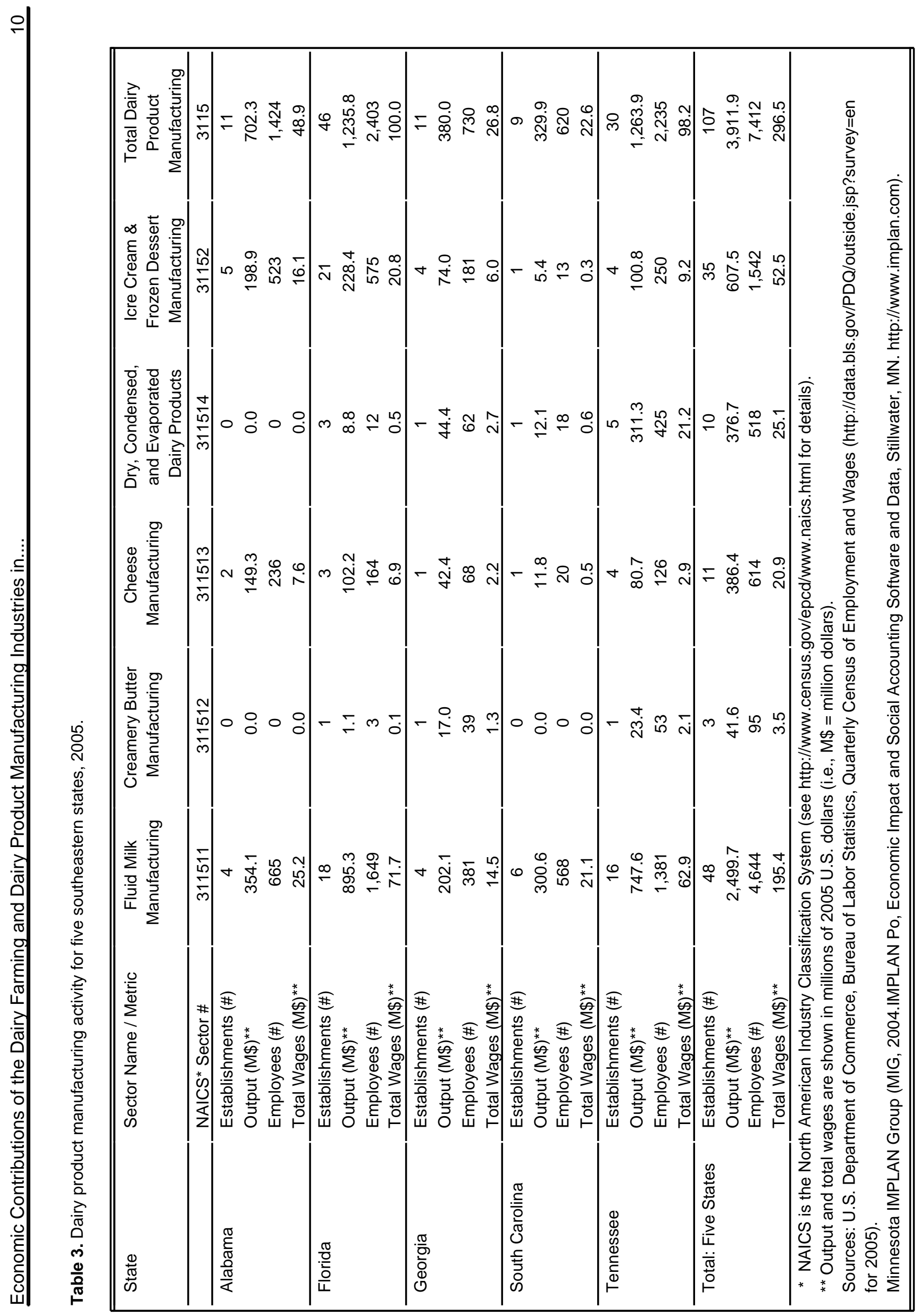




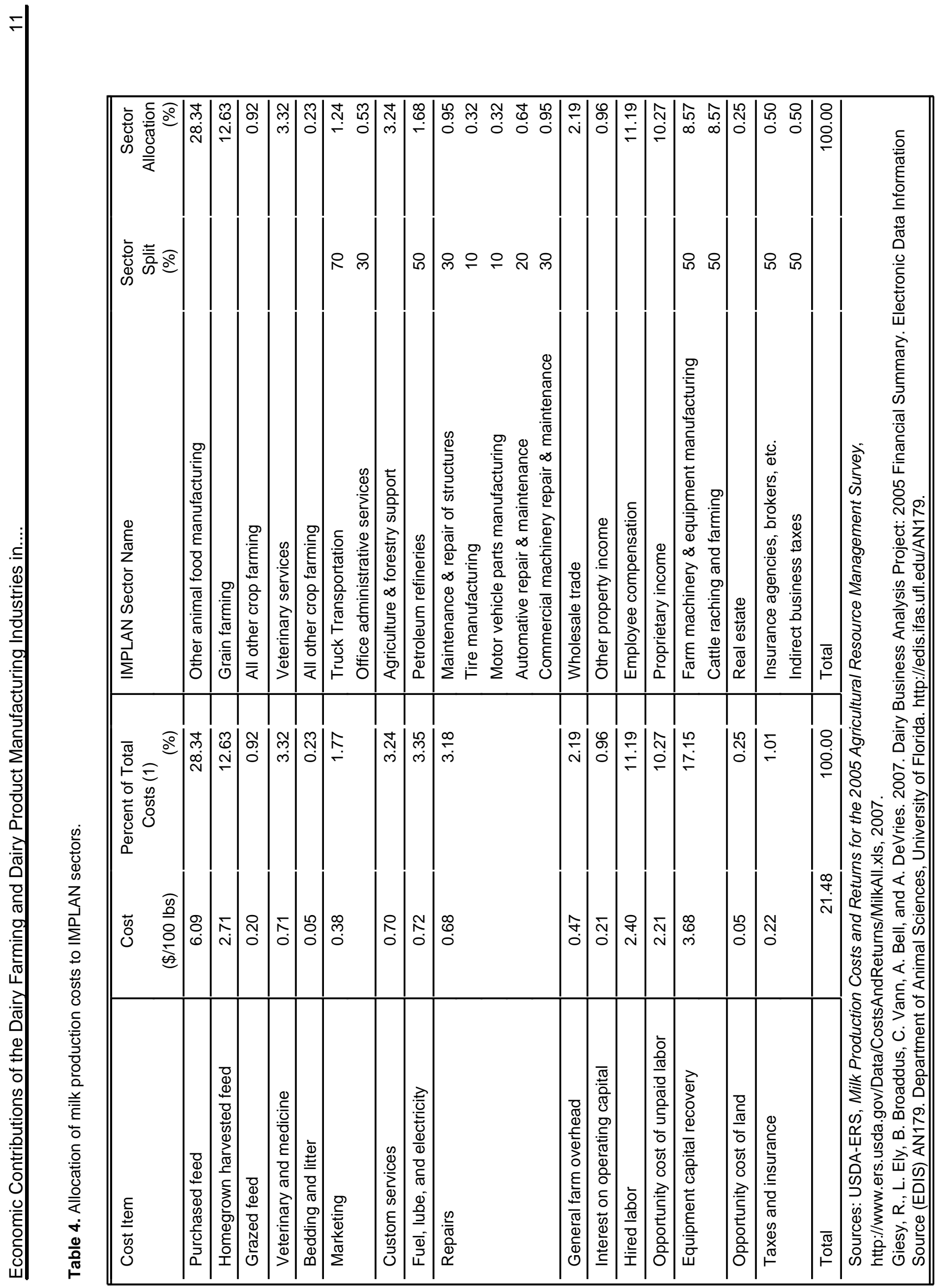




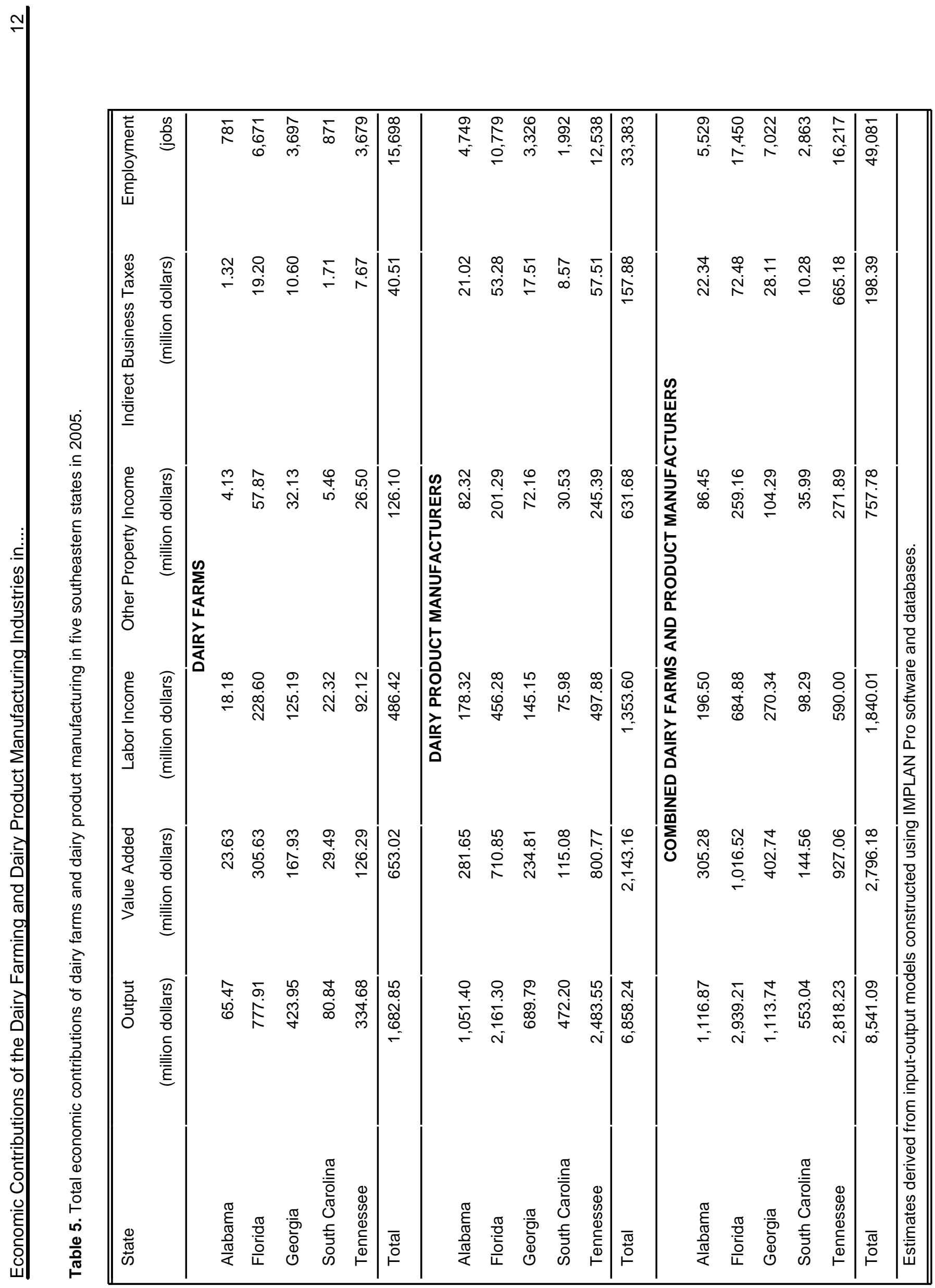




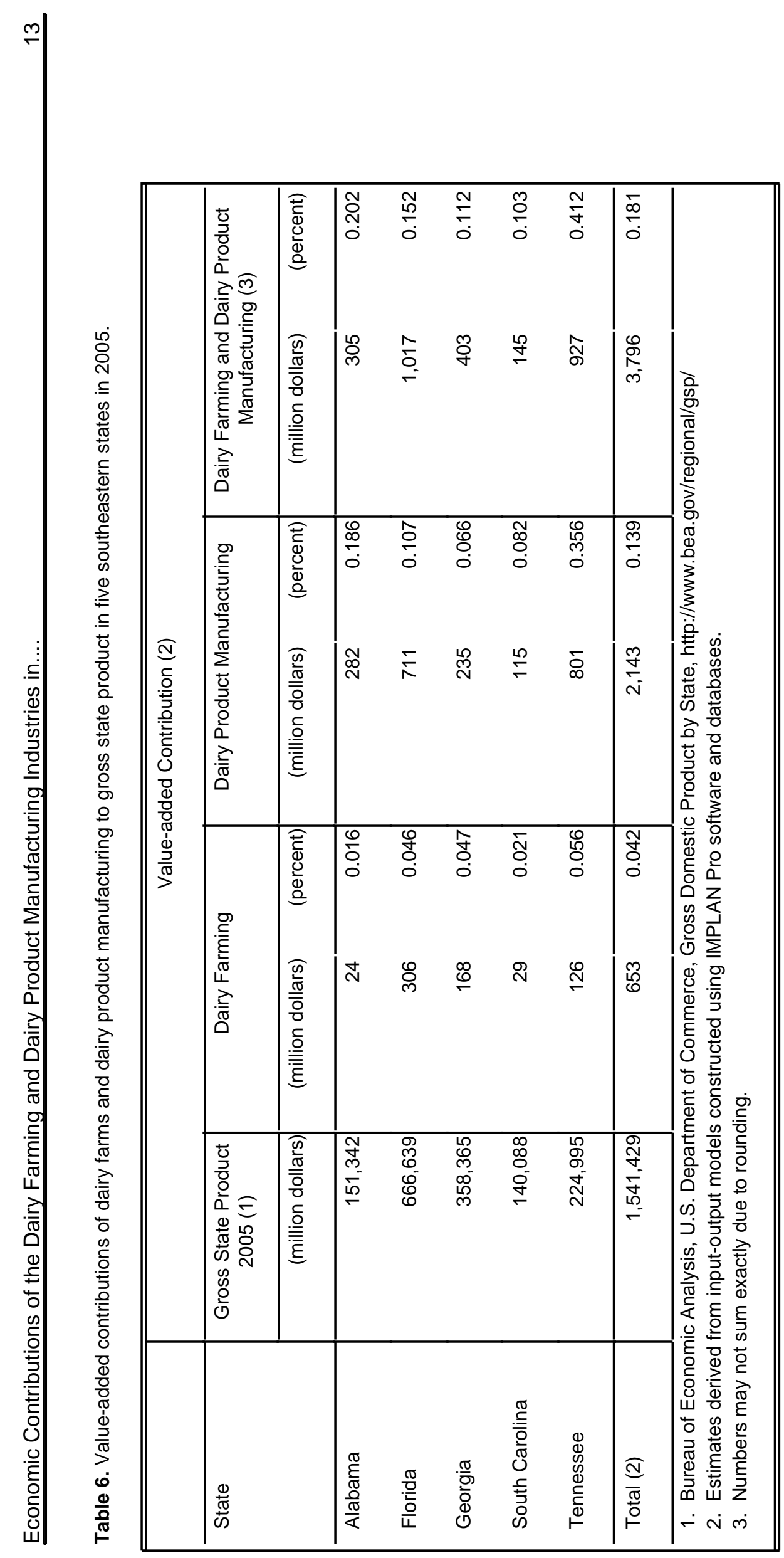


Table 7. EIT Glossary

\section{Glossary of Economic Impact Terminology}

Direct effects / impacts: The revenues, value-added, income, or jobs that result directly from an economic activity within a regional economy.

Employment or Jobs: The total numbers of wage and salaried employees as well as self-employed jobs, including full-time, part-time, and seasonal workers measured in annual average jobs.

Indirect Business Taxes: Include sales, excise, and property taxes as well as fees and licenses paid by businessess during normal operations. It does not include taxes on profits or income.

Indirect Effects / Impacts: Occur when businesses use revenues originating from outside the region to purchase inputs (goods and services) from local suppliers. Also, generates additional revenues, income, jobs, and taxes for the area economy.

Induced Effects / Impacts: Only occur when new or outside dollars are introduced into a local economy. Induced economic impacts occur as the households of business owners and employees spend their earnings from these enterprises to purchase consumer goods and serives from other businesses within the region. This induced effect generates additional revenues, income, jobs, and taxes for the area economy.

Input-Output Analysis: The use of input-output models to estimate how revenues or employment for one or more particular industries, businesses, or events in a regional economy will impact other businesses and institutions in that region.

Input-Output Models: A mathematical representation of economic activity within a defined region using inter-industry transaciton tables or matices where the outputs of various industries are used as inputs by those same industries and other industries as well.

Labor Income: All forms of employment compensation, including employee wages and salaries, and proprietor income or profits.

Local Revenues / Expenditures: Simple transfers between individuals or businesses within a regional economy. These transactiosn do not generate economic spin-off or multiplier (indirect and induced) effects.

Non-local Revenues / Expenditures: When outside or new revenues flow into a local economy either from the sale of locally produced goods and services to points outside the study area, or from expenditures by non-local visitors to the study area, additional economic repercussions occur through indirect and induced effects.

Other Property Type Income: Corporate profits in addition to payments for rents, royalties, dividends, and interest.

Output: Reveues or sales associated with an industry or economic activity.

Total Impacts: The sum of direct, indirect, and induced effects or economic impacts.

Value-added: Includes wages and salaries, interest, rent, profits, and indirect taxes paid by businesses, and represents the activity's contribution to Gross Domestic or State Product. 


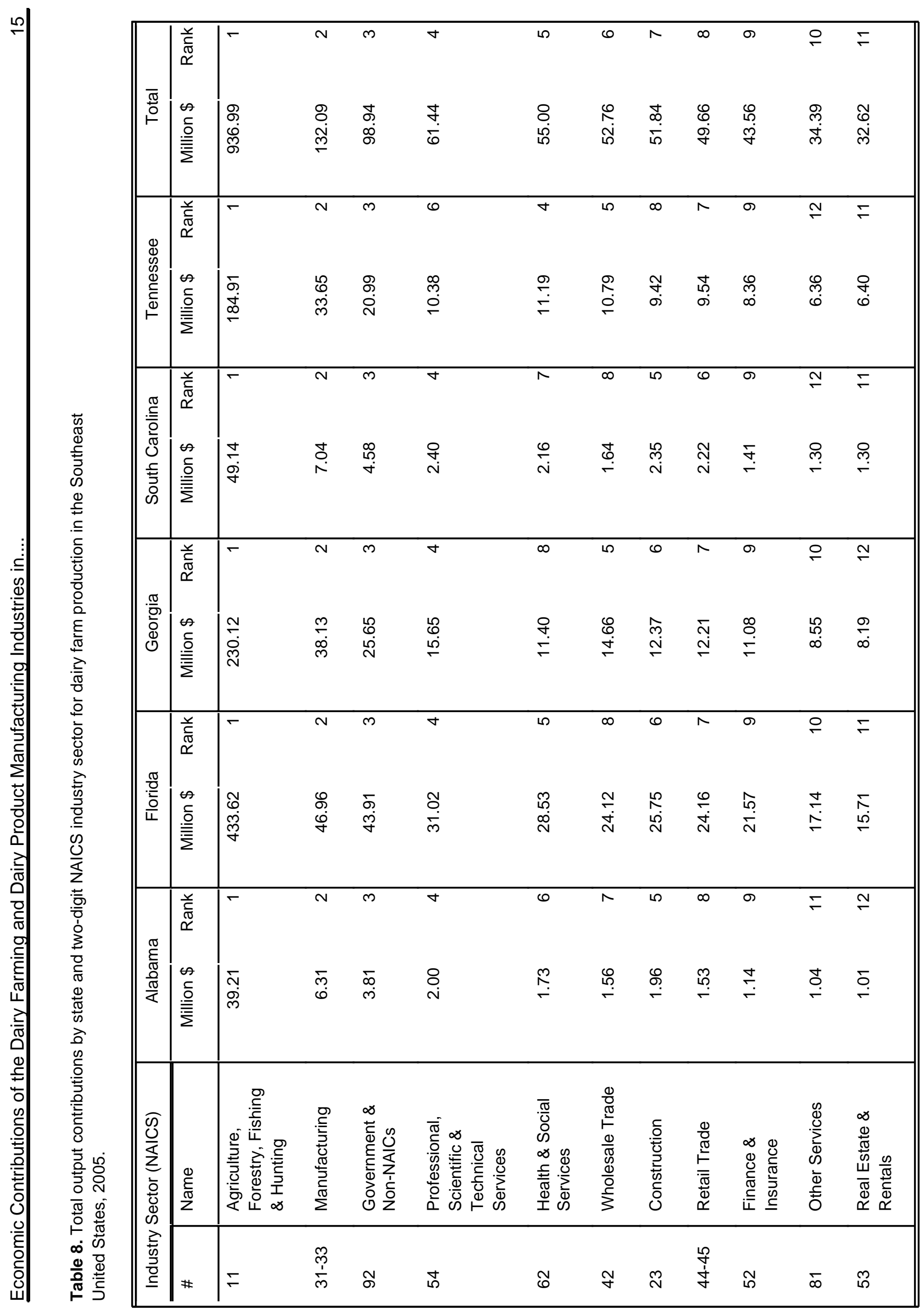




\begin{tabular}{|c|c|c|c|c|c|c|c|c|c|c|c|c|c|}
\hline \multirow{8}{*}{ 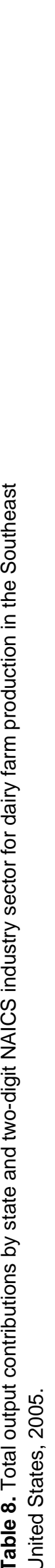 } & $\begin{array}{l}\overline{\bar{\pi}} \\
\stackrel{0}{0}\end{array}$ & 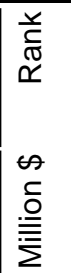 & 㐫 & $\begin{array}{l}\text { @̊ } \\
\stackrel{\text { مैं }}{ }\end{array}$ & $\begin{array}{l}\stackrel{\nabla}{\leftarrow} \\
\stackrel{\infty}{\leftarrow} \\
\stackrel{\infty}{N}\end{array}$ & $\begin{array}{l}\emptyset \\
\emptyset \\
\infty\end{array}$ & 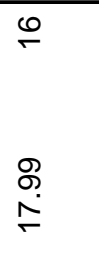 & ণ & $\begin{array}{c}\overline{0} \\
\dot{0}\end{array}$ & $\begin{array}{l}\text { m్ } \\
\text { ம் }\end{array}$ & & 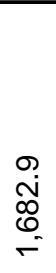 & \\
\hline & 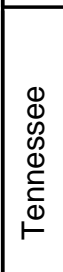 & 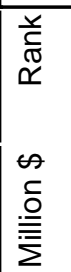 & $\mid \begin{array}{c}0 \\
0 \\
0\end{array}$ & $\begin{array}{l}8 \\
\text { in }\end{array}$ & $\begin{array}{c}\hat{A} \\
0\end{array}$ & $\begin{array}{l}\stackrel{\text { P }}{\oplus} \\
\text { ले }\end{array}$ & $\frac{10}{m}$ & $\stackrel{s}{\circ}$ & $\stackrel{\text { L }}{\circ}$ & $\stackrel{ }{\stackrel{ }{\leftarrow}}$ & 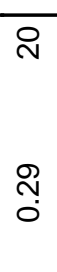 & $\begin{array}{l}\infty \\
@ \\
\dot{m} \\
\text { ల్ల }\end{array}$ & \\
\hline & 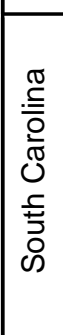 & 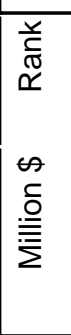 & $\stackrel{m}{\stackrel{m}{n}}$ & $\stackrel{\oplus}{\check{r}}$ & 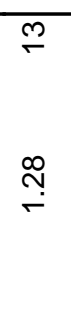 & $\begin{array}{l}\text { مٌ } \\
\text { مٌ }\end{array}$ & $\begin{array}{l}\text { Oे } \\
\text { o }\end{array}$ & $\frac{0}{\circ}$ & 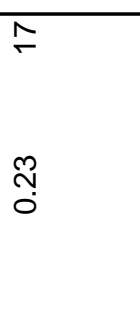 & $\underset{N}{\tilde{O}}$ & $\begin{array}{l}\overline{0} \\
\end{array}$ & $\begin{array}{l}\text { ¿े } \\
\infty \\
\infty\end{array}$ & \multirow{6}{*}{ 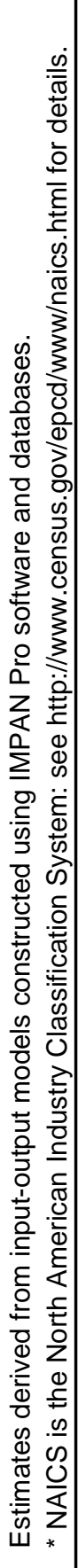 } \\
\hline & $\begin{array}{l}\frac{\pi}{\sigma} \\
\overline{0} \\
\overline{0} \\
0\end{array}$ & 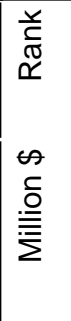 & $\begin{array}{l}M \\
\infty \\
\infty\end{array}$ & $\frac{\sigma}{\dot{\theta}}$ & $\stackrel{8}{\circ}$ & $\begin{array}{l}\stackrel{\circ}{\circ} \\
\forall\end{array}$ & $\underset{\forall}{\stackrel{\forall}{*}}$ & $\stackrel{\bar{o}}{\text { N }}$ & $\stackrel{\text { p) }}{-}$ & $\stackrel{\text { p̧ }}{\leftarrow}$ & $\begin{array}{l}\text { No } \\
\text {. }\end{array}$ & $\begin{array}{l}\stackrel{2}{\circ} \\
\text { ָे } \\
\text { † }\end{array}$ & \\
\hline & $\frac{\frac{\pi}{ㅇ}}{\frac{0}{}}$ & 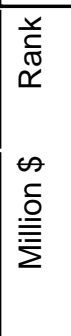 & $\begin{array}{l}\hat{\omega} \\
\stackrel{\leftrightarrow}{\sim}\end{array}$ & $\begin{array}{l}\stackrel{\mathcal{O}}{L} \\
\stackrel{\sim}{\sim}\end{array}$ & $\stackrel{ }{\check{r}}$ & $\begin{array}{l}\bar{N} \\
\sigma\end{array}$ & 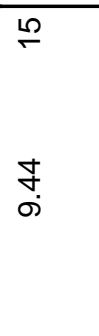 & $\begin{array}{l}\varrho \\
\stackrel{\infty}{\infty}\end{array}$ & $\begin{array}{l}\stackrel{\Re}{n} \\
\text { }\end{array}$ & 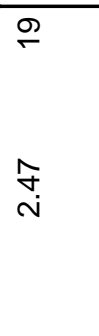 & $\underset{+}{-}$ & $\begin{array}{l}\text { o } \\
\stackrel{N}{N}\end{array}$ & \\
\hline & 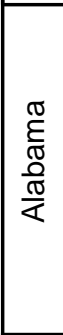 & 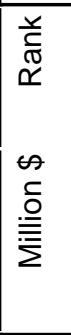 & $\stackrel{\text { o }}{-}$ & $\begin{array}{l}\infty \\
\stackrel{\infty}{0} \\
\vdots\end{array}$ & $\begin{array}{l}\stackrel{\infty}{\infty} \\
0 \\
0\end{array}$ & 守 & $\underset{\stackrel{f}{\circ}}{\text { for }}$ & $\frac{m}{\circ}$ & $\frac{\circ}{\circ}$ & $\frac{m}{\circ}$ & $\frac{0}{\circ}$ & $\begin{array}{l}\text { 于े } \\
\text { i̊ }\end{array}$ & \\
\hline & $\begin{array}{l}\widehat{D} \\
0 \\
\frac{0}{\pi} \\
\vdots \\
\overline{0} \\
\frac{0}{0} \\
\infty \\
\infty\end{array}$ & $\begin{array}{l}\stackrel{0}{E} \\
\stackrel{\mathbb{N}}{Z}\end{array}$ & 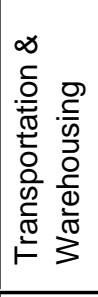 & 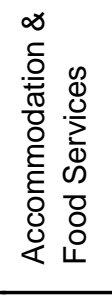 & 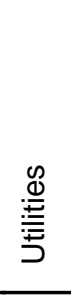 & 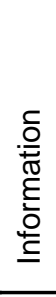 & 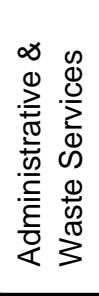 & 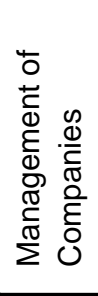 & 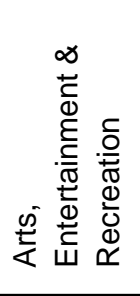 & 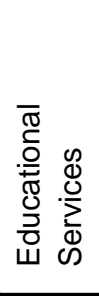 & 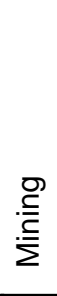 & $\begin{array}{l}\bar{\pi} \\
\text { ర0 }\end{array}$ & \\
\hline & $\begin{array}{l}\overline{\overline{\bar{D}}} \\
\overline{\underline{D}} \\
\underline{\underline{\underline{g}}}\end{array}$ & $\#$ & $\begin{array}{l}\stackrel{g}{\checkmark} \\
\text { o }\end{array}$ & $\stackrel{N}{N}$ & స & 5 & $\mathscr{L}$ & $\stackrel{L}{\circ}$ & $\bar{\lambda}$ & $\bar{\omega}$ & $\bar{N}$ & & \\
\hline
\end{tabular}




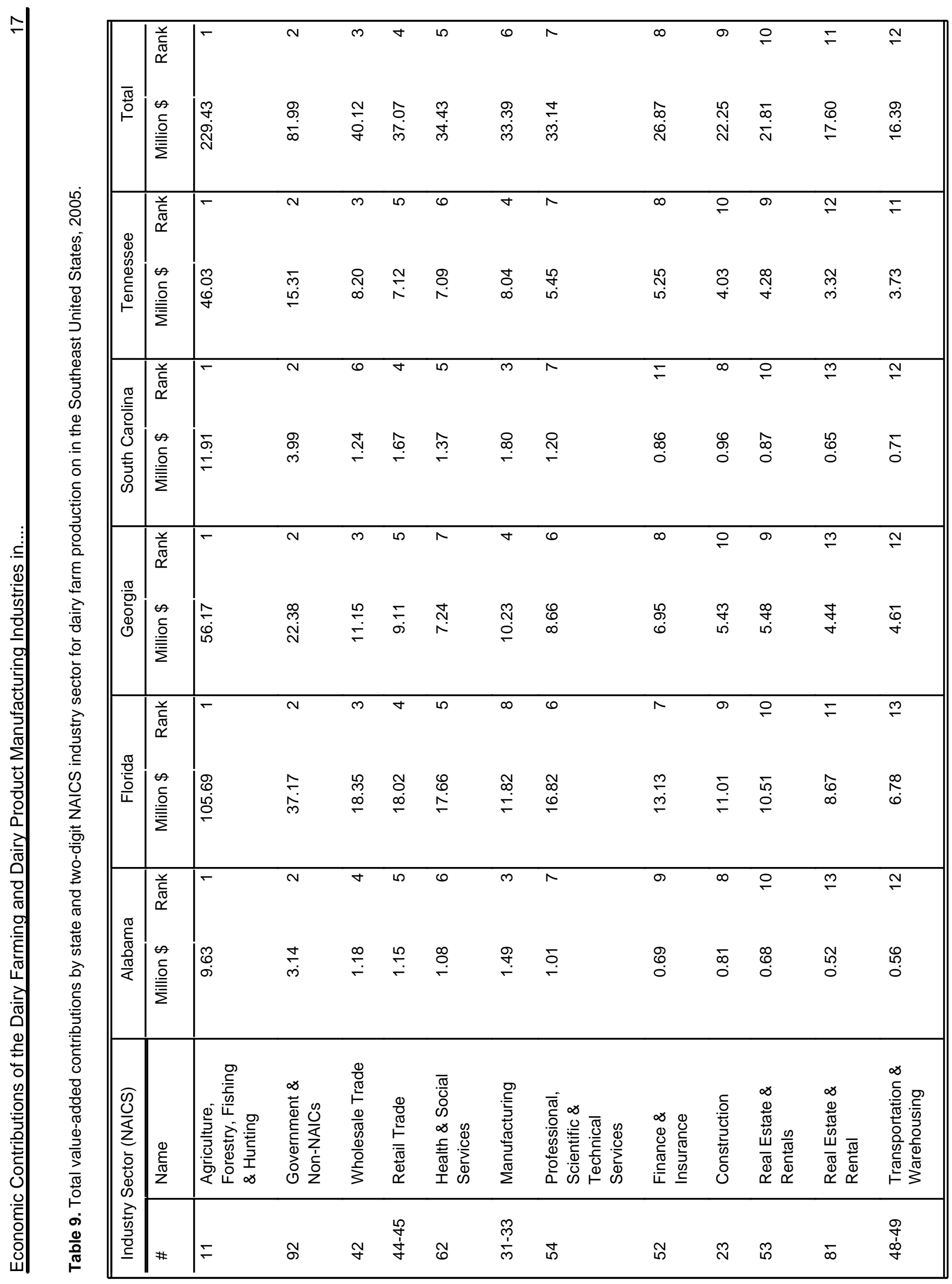




\begin{tabular}{|c|c|c|c|c|c|c|c|c|c|c|c|c|}
\hline & $\begin{array}{l}\bar{\pi} \\
\frac{\pi}{0}\end{array}$ & 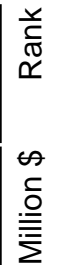 & $\begin{array}{l}\stackrel{+}{N} \\
\stackrel{+}{\sim}\end{array}$ & $\begin{array}{l}\ddot{O} \\
\stackrel{\oplus}{\leftarrow}\end{array}$ & $\begin{array}{l}\text { P } \\
\text { ㅇ }\end{array}$ & $\begin{array}{l}\dot{D} \\
\infty \\
\infty\end{array}$ & $\frac{m}{\sim}$ & $\begin{array}{l}\infty \\
\stackrel{\infty}{\infty}\end{array}$ & $\begin{array}{l}\infty \\
\text { O } \\
\text { ल. }\end{array}$ & $\stackrel{\text { ִֻ }}{\circ}$ & 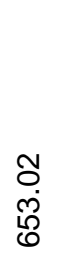 & \\
\hline 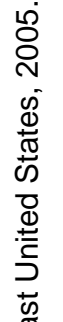 & 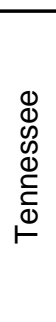 & 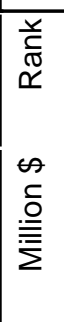 & $\underset{\stackrel{\infty}{+}}{\stackrel{\infty}{\circ}}$ & $\begin{array}{l}\underset{N}{N} \\
\stackrel{N}{N}\end{array}$ & $\stackrel{\infty}{\infty}$ & 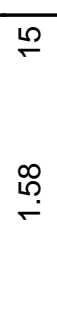 & $\begin{array}{l}\stackrel{0}{0} \\
\stackrel{0}{ }\end{array}$ & $\begin{array}{l}\mathscr{0} \\
\stackrel{\bullet}{0}\end{array}$ & $\begin{array}{l}\mathscr{O} \\
\stackrel{0}{0}\end{array}$ & $\begin{array}{l}\infty \\
\stackrel{\circ}{\circ}\end{array}$ & 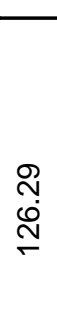 & \\
\hline 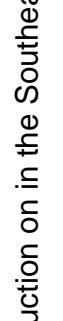 & 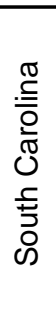 & 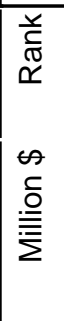 & б. & $\begin{array}{l}0 \\
\stackrel{1}{0} \\
0\end{array}$ & స̃ & 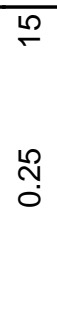 & $\begin{array}{l}\text { O) } \\
\circ \\
0\end{array}$ & $\stackrel{\nabla}{\check{0}}$ & $\bar{\sigma}$ & ○ & $\begin{array}{l}\stackrel{9}{+} \\
\text { ه্ }\end{array}$ & 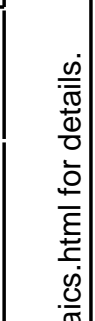 \\
\hline 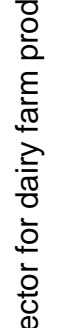 & $\begin{array}{l}\frac{\pi}{\pi} \\
\overline{0} \\
0 \\
0\end{array}$ & 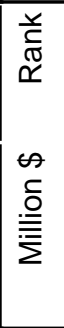 & $\underset{\forall}{\sigma}$ & $\underset{m}{\stackrel{\circ}{\circ}}$ & 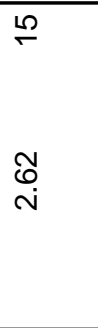 & 芯 & 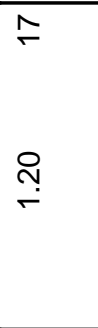 & $\begin{array}{c}\hat{\infty} \\
0 \\
0\end{array}$ & $\begin{array}{l}\text { O } \\
0 \\
0\end{array}$ & Jo & 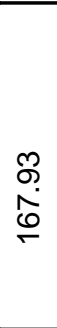 & 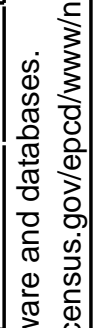 \\
\hline 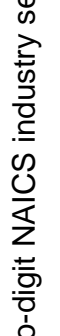 & $\frac{\frac{\pi}{}}{\frac{0}{4}}$ & 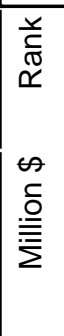 & $\mid \begin{array}{l}\infty \\
\infty \\
\\
\end{array}$ & $\begin{array}{l}\infty \\
\stackrel{0}{*}\end{array}$ & $\begin{array}{l}\text { N̦ } \\
\text { مْ }\end{array}$ & $\underset{\sim}{\stackrel{N}{\sim}}$ & $\frac{\infty}{\grave{N}}$ & $\begin{array}{l}\mathscr{Q} \\
\stackrel{\text { N }}{ }\end{array}$ & $\underset{\forall}{\stackrel{\forall}{*}}$ & $\begin{array}{l}\text { N̦ } \\
\text { On }\end{array}$ & $\begin{array}{l}\infty \\
0 \\
\mathscr{\rho} \\
\text { م) }\end{array}$ & 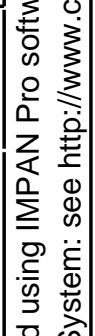 \\
\hline $\begin{array}{l}\frac{3}{3} \\
0 \\
\frac{1}{0} \\
0 \\
0 \\
\frac{\pi}{01} \\
0 \\
0 \\
0 \\
0 \\
0 \\
0 \\
\overline{0} \\
0\end{array}$ & 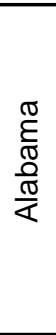 & 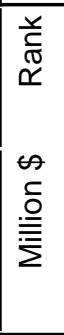 & 垈 & $\begin{array}{l}0 \\
\text { m. } \\
0\end{array}$ & $\begin{array}{l}\stackrel{\leftrightarrow}{\sim} \\
\stackrel{0}{0}\end{array}$ & $\begin{array}{l}\stackrel{\Upsilon}{0} \\
\text { }\end{array}$ & $\begin{array}{l}\hat{O} \\
\circ\end{array}$ & $\begin{array}{l}\mathscr{8} \\
\stackrel{0}{0}\end{array}$ & O & 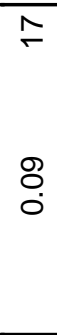 & $\begin{array}{l}\mathscr{\bigotimes} \\
\text { ஸे }\end{array}$ & 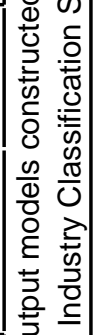 \\
\hline $\begin{array}{l}\frac{5}{0} \\
0 \\
0 \\
\frac{0}{0} \\
\frac{0}{0} \\
\frac{1}{0} \\
\frac{0}{\pi} \\
\frac{\pi}{2} \\
\frac{\pi}{0}\end{array}$ & $\begin{array}{l}\text { क } \\
\frac{0}{\vdots} \\
\vdots \\
\overline{0} \\
\frac{0}{0} \\
\infty\end{array}$ & $\frac{\mathbb{\Phi}}{\stackrel{\mathbb{\pi}}{Z}}$ & 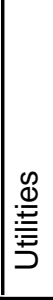 & 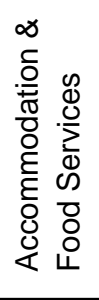 & 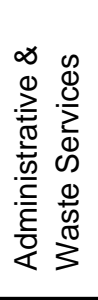 & 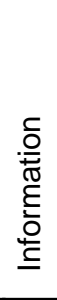 & 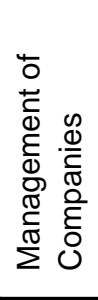 & 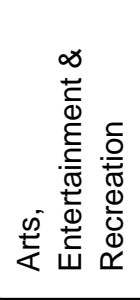 & 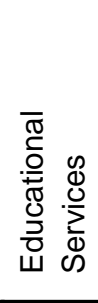 & & $\begin{array}{l}\bar{\pi} \\
\frac{\pi}{0}\end{array}$ & 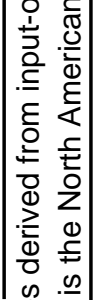 \\
\hline$\frac{\frac{0}{0}}{\frac{10}{10}}$ & $\begin{array}{l}\overline{\underline{z}} \\
\underline{\underline{\underline{S}}}\end{array}$ & $\#$ & $\tilde{N}$ & $\mathfrak{N}$ & $\underset{\kappa}{0}$ & 5 & م & $\Sigma$ & $\overline{6}$ & $\bar{N}$ & & 点 $\bar{z}$ \\
\hline
\end{tabular}




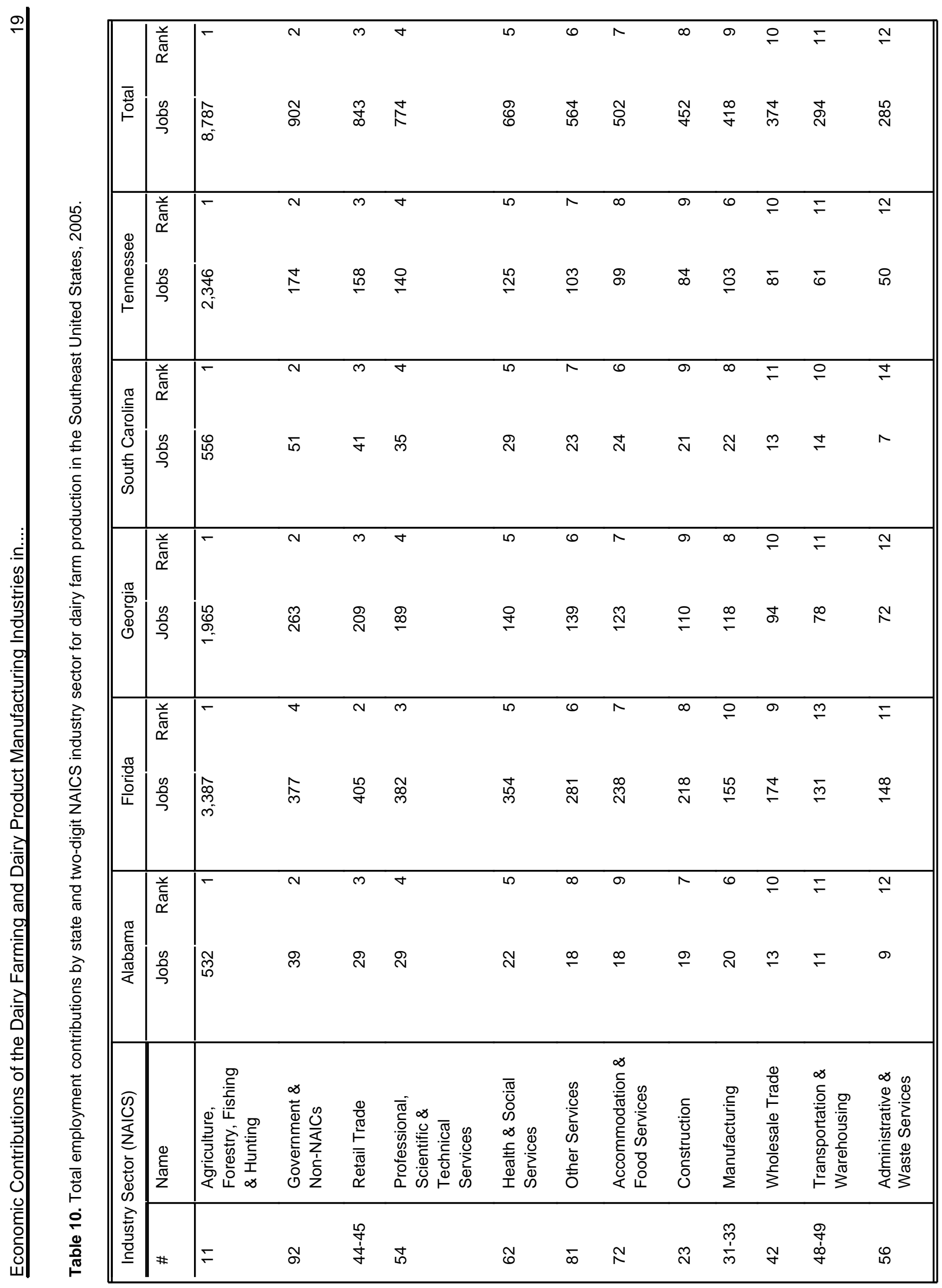




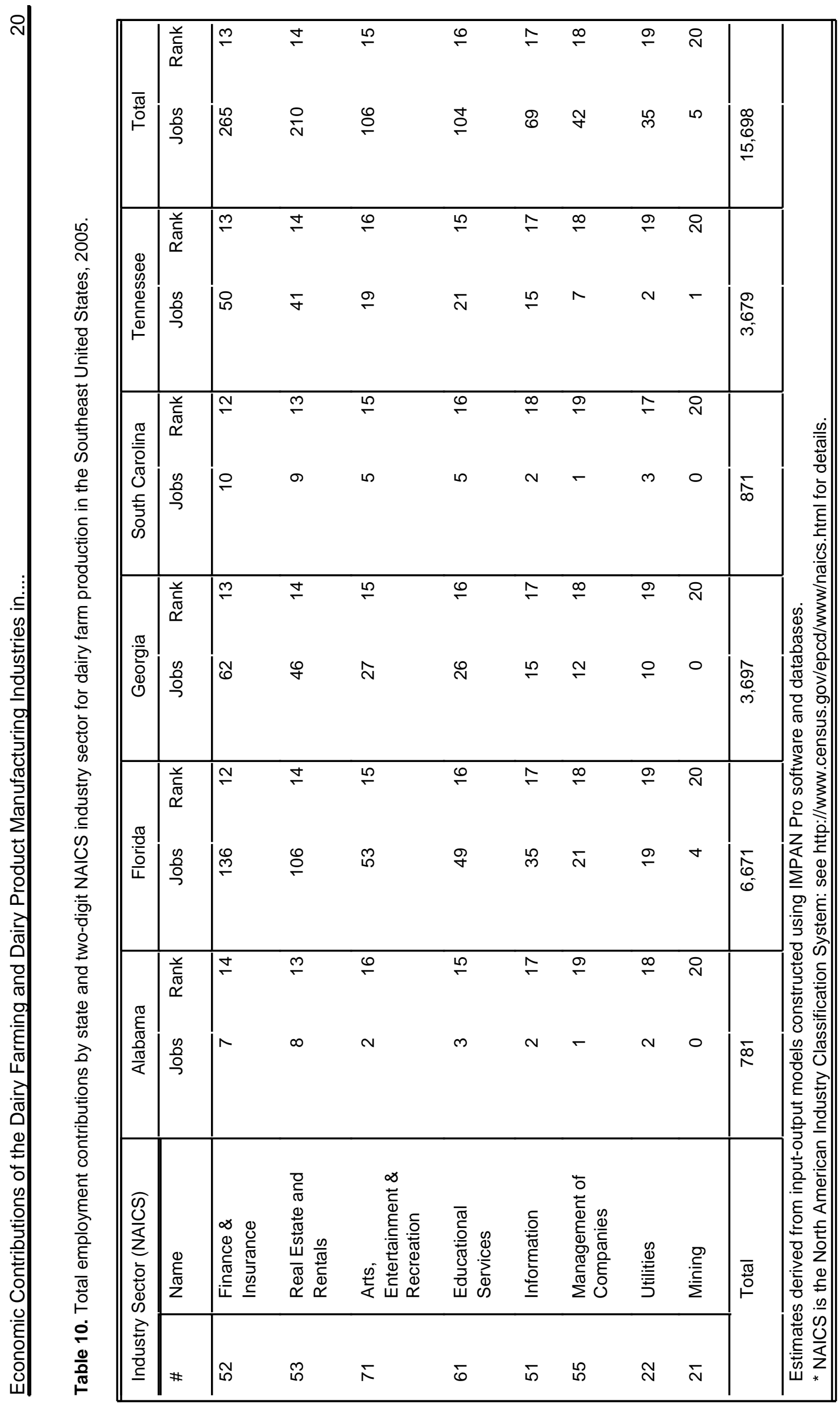




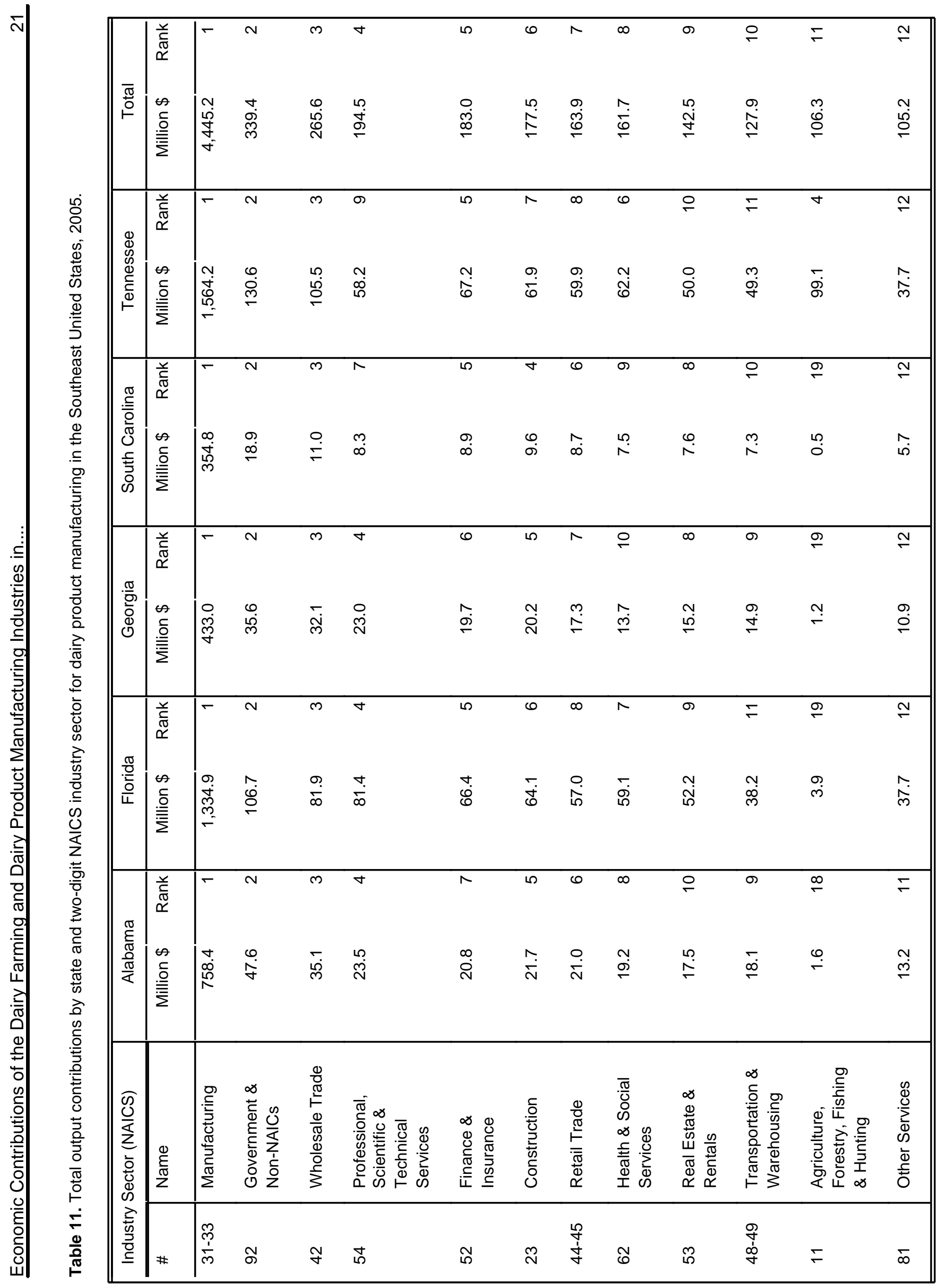




\begin{tabular}{|c|c|c|c|c|c|c|c|c|c|c|c|c|}
\hline & $\begin{array}{l}\bar{\pi} \\
\stackrel{0}{0} \\
\end{array}$ & 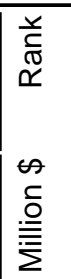 & $\mid \begin{array}{l}\frac{m}{-} \\
\frac{1}{0}\end{array}$ & 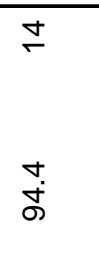 & $\begin{array}{l}\dot{0} \\
\infty\end{array}$ & $\begin{array}{l}\infty \\
\ddot{\theta}\end{array}$ & 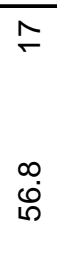 & 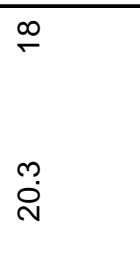 & $\begin{array}{l}\text { O) } \\
\stackrel{0}{\circ}\end{array}$ & $\dot{0}$ & $\begin{array}{l}0 \\
0 \\
\not \\
\infty \\
0 \\
0\end{array}$ & \\
\hline 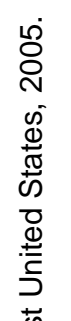 & 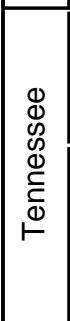 & 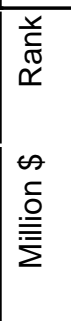 & $\mid \begin{array}{l}\infty \\
\stackrel{\infty}{\infty} \\
\stackrel{\infty}{N}\end{array}$ & $\begin{array}{l}\stackrel{m}{\circ} \\
\stackrel{0}{\infty}\end{array}$ & Ṇ & 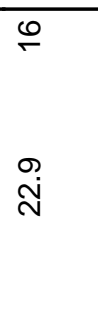 & ம. & $\stackrel{0}{\wedge}$ & $\ddot{\theta}$ & $\stackrel{+}{\leftarrow}$ & 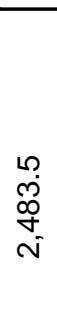 & \\
\hline 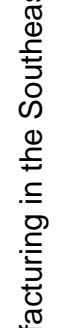 & 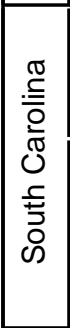 & 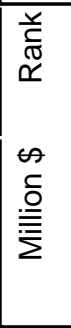 & $\stackrel{\infty}{\dot{\forall}}$ & $\hat{\omega}$ & $\stackrel{\varphi}{\infty}$ & $\overline{c i}$ & $\begin{array}{l}0 \\
10 \\
10\end{array}$ & $\stackrel{\circ}{\circ}$ & $\infty$ & $\because$ & $\begin{array}{l}\stackrel{N}{N} \\
\stackrel{N}{+}\end{array}$ & 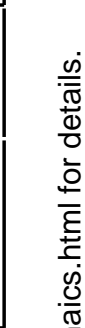 \\
\hline 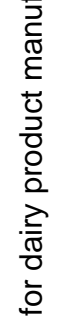 & \begin{tabular}{|l|}
$\frac{\pi}{0}$ \\
$\frac{0}{2}$ \\
$\frac{1}{0}$ \\
0
\end{tabular} & 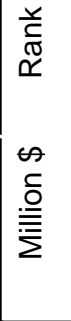 & 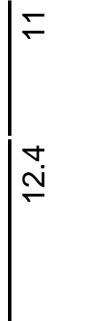 & $\begin{array}{l}\stackrel{L}{\sim} \\
\stackrel{+}{\circ}\end{array}$ & $\check{0}$ & $\stackrel{\circ}{\sim}$ & $\begin{array}{l}\stackrel{7}{\leftarrow} \\
\stackrel{\infty}{\infty}\end{array}$ & $\begin{array}{l}\hat{\sim} \\
\overline{\mathrm{N}}\end{array}$ & 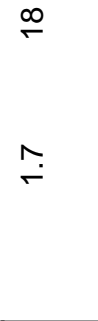 & $\overline{0}$ & $\begin{array}{l}\infty \\
\stackrel{\infty}{0} \\
\infty \\
0\end{array}$ & 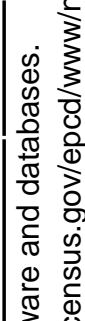 \\
\hline 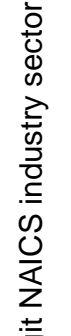 & $\frac{\frac{\pi}{0}}{\frac{0}{4}}$ & 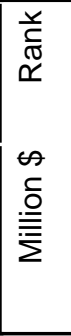 & $\mid \begin{array}{l}0 \\
\dot{\rho} \\
\dot{\varphi}\end{array}$ & $\begin{array}{l}\infty \\
\stackrel{m}{m}\end{array}$ & $\bar{m}$ & $\begin{array}{l}\stackrel{0}{\dot{N}} \\
\dot{N}\end{array}$ & $\stackrel{\sim}{\stackrel{N}{d}}$ & $\underset{\infty}{\infty}$ & $\stackrel{\infty}{\infty}$ & $\stackrel{N}{N}$ & $\begin{array}{l}\frac{m}{\infty} \\
\frac{\omega}{i}\end{array}$ & 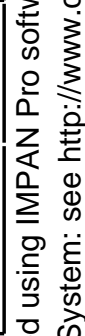 \\
\hline 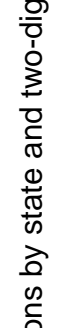 & $\begin{array}{l}\frac{\pi}{\pi} \\
\frac{\pi}{\pi} \\
\frac{0}{\pi} \\
\frac{\pi}{<}\end{array}$ & 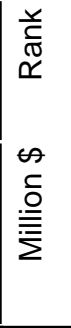 & 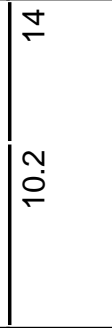 & 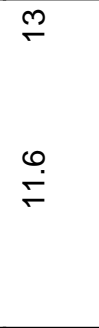 & $\stackrel{\circ}{\infty}$ & Ṇ & $\stackrel{\infty}{\leftarrow}$ & $\stackrel{\forall}{r}$ & $\begin{array}{l}\stackrel{9}{+} \\
\stackrel{?}{\circ}\end{array}$ & 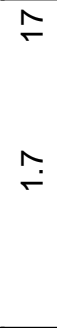 & 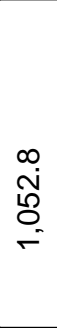 & 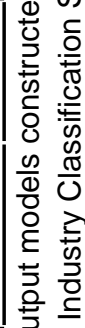 \\
\hline 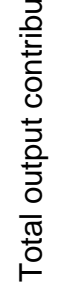 & $\begin{array}{l}\widehat{D} \\
0 \\
\frac{0}{\pi} \\
\vdots \\
\vdots \\
\overline{0} \\
0 \\
0\end{array}$ & $\begin{array}{l}\stackrel{0}{E} \\
\stackrel{\pi}{Z}\end{array}$ & 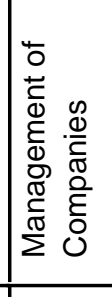 & 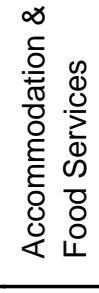 & 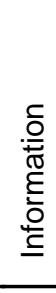 & 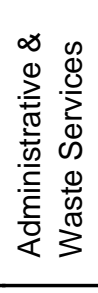 & 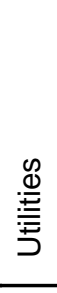 & 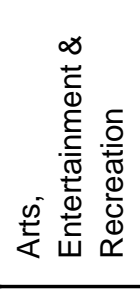 & 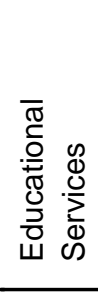 & $\begin{array}{l}\text { D) } \\
\stackrel{\text { D }}{\sum}\end{array}$ & $\begin{array}{l}\bar{\pi} \\
\stackrel{\sigma}{0} \\
\end{array}$ & 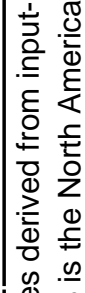 \\
\hline$\frac{\frac{0}{0}}{\frac{0}{\sigma}}$ & $\underline{\underline{z}}$ & \# & م & $\mathfrak{N}$ & in & $\mathscr{6}$ & N & $\bar{\lambda}$ & $\bar{\sigma}$ & $\bar{v}$ & & 敨 \\
\hline
\end{tabular}




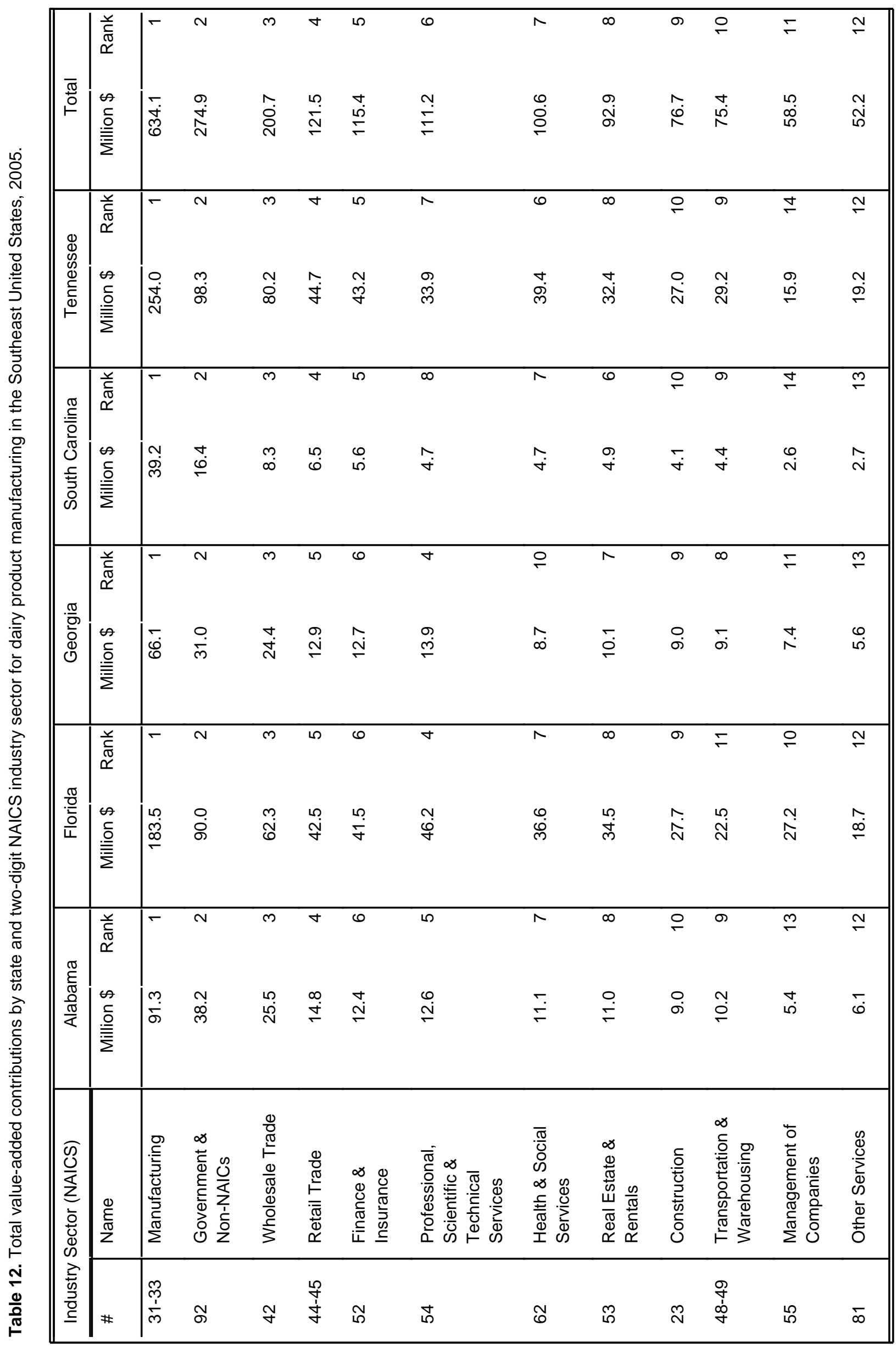




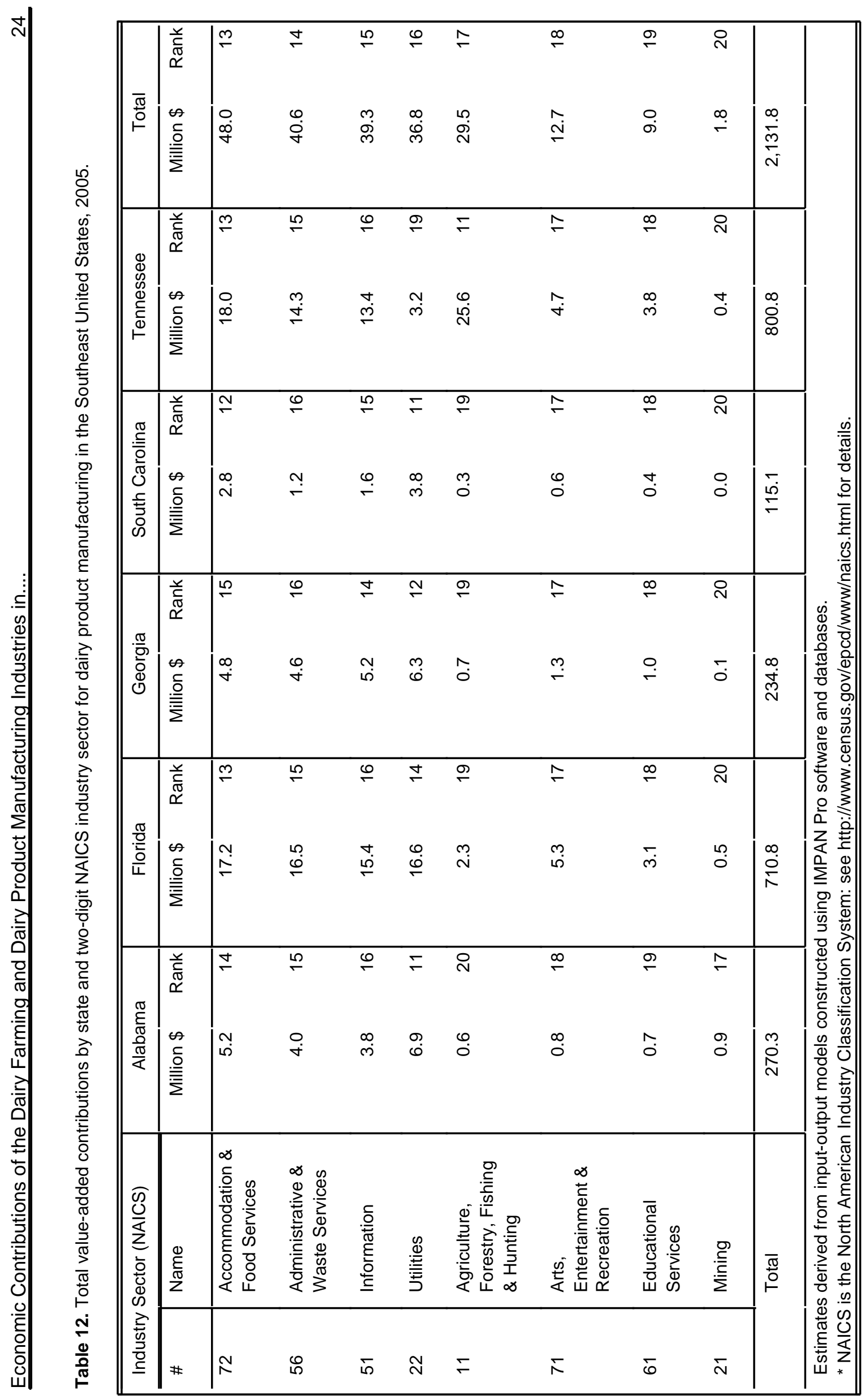




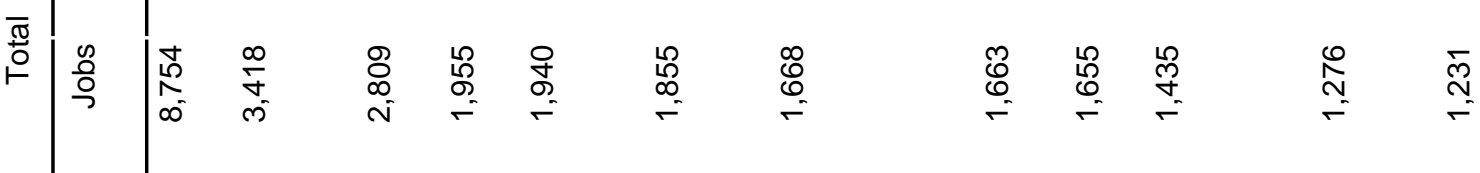

\begin{tabular}{|c|c|c|c|c|c|c|c|c|c|c|c|c|c|}
\hline $\begin{array}{l}\bar{\sigma} \\
\stackrel{0}{0} \\
\vdash\end{array}$ & 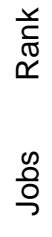 & $\mid \begin{array}{l}\text { 先 } \\
\stackrel{\infty}{\infty} \\
\infty\end{array}$ & $\frac{\infty}{\dot{v}}$ & $\begin{array}{l}\text { D } \\
\infty \\
\text { N }\end{array}$ & مٌ & 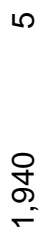 & $\begin{array}{l}\stackrel{1}{\infty} \\
\infty \\
-\end{array}$ & \begin{tabular}{l}
$\infty$ \\
0 \\
0 \\
\hdashline
\end{tabular} & $\begin{array}{l}\text { ల్ } \\
\text { ర్ } \\
-\end{array}$ & 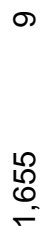 & 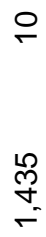 & 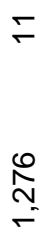 & 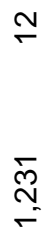 \\
\hline & $\begin{array}{l}\stackrel{Y}{\mathbb{C}} \\
\mathbb{N}\end{array}$ & - & m & $\nabla$ & 10 & 6 & $\Lambda$ & 음 & $\sigma$ & $\infty$ & $N$ & $\mp$ & $N$ \\
\hline
\end{tabular}

仓્ळ

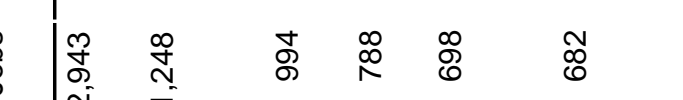

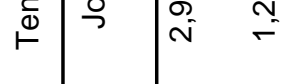

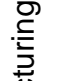

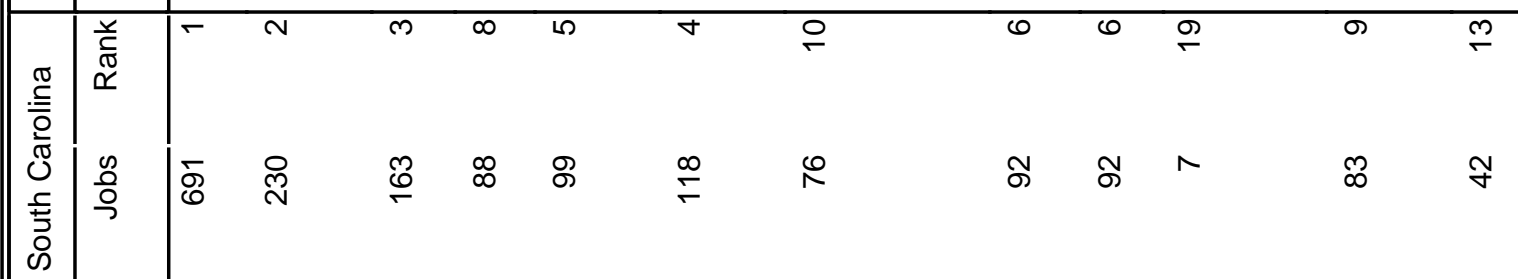

䨔 क

ह

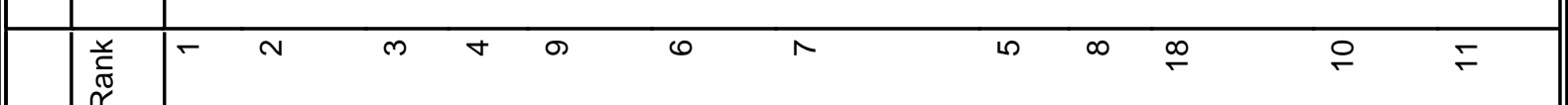

$\frac{\pi}{\overline{2}}$

ত

흥

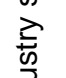

$\frac{\mathscr{O}}{\mathrm{D}}$

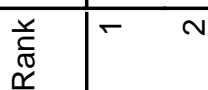

$\begin{array}{lllll} & \infty & \infty & \forall & 0\end{array}$

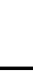

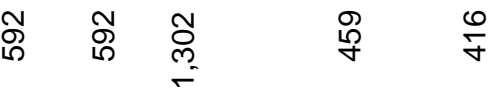

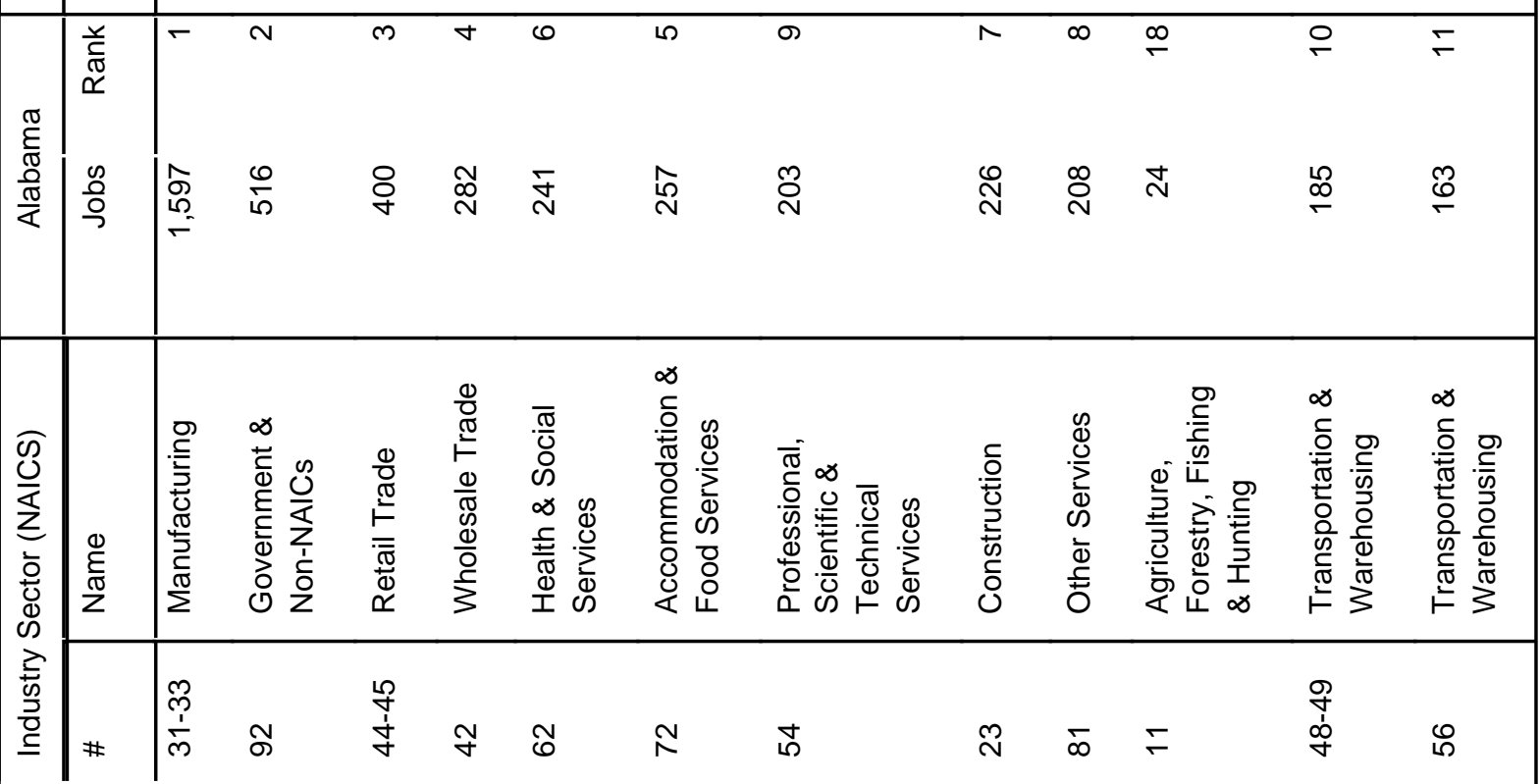




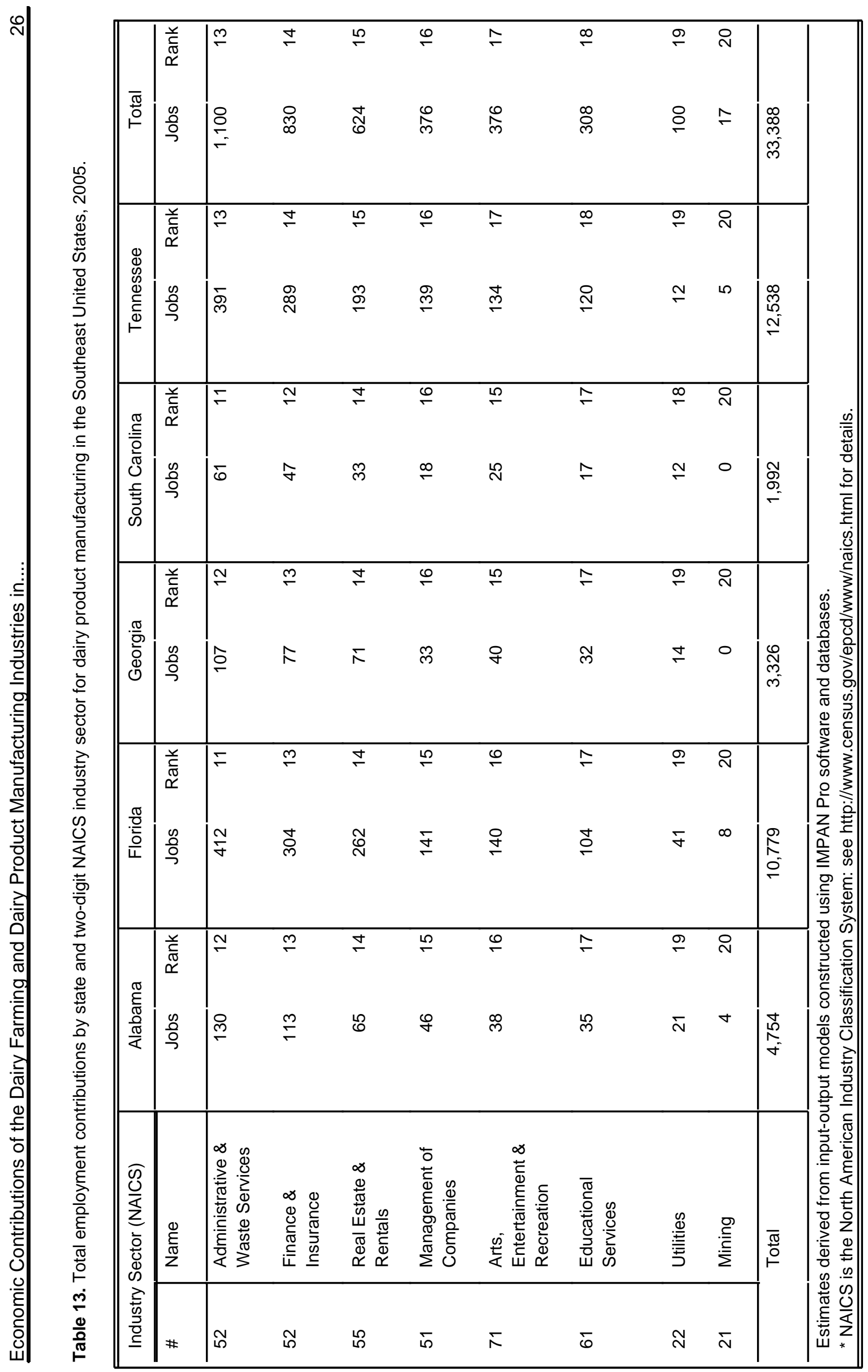




\begin{tabular}{|c|c|c|c|c|c|c|c|c|c|c|c|c|c|c|}
\hline 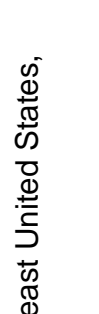 & $\begin{array}{l}\overline{\widetilde{\pi}} \\
\stackrel{0}{\circ}\end{array}$ & 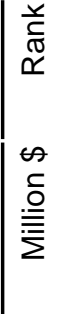 & 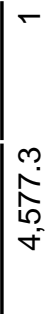 & $\begin{array}{l}\infty \\
\stackrel{\infty}{\tilde{P}} \\
\stackrel{0}{0} \\
\stackrel{-}{-}\end{array}$ & $\begin{array}{l}\stackrel{+}{+} \\
\stackrel{9}{q}\end{array}$ & $\begin{array}{l}\infty \\
\infty \\
\infty \\
\infty\end{array}$ & $\begin{array}{l} \\
\circ \\
\dot{0} \\
\stackrel{N}{N}\end{array}$ & ষ্ণ & $\begin{array}{l} \\
10 \\
\stackrel{\leftrightarrow}{0}\end{array}$ & $\begin{array}{l}\infty \\
\hat{\omega} \\
\stackrel{\omega}{N}\end{array}$ & $\frac{\omega}{\stackrel{m}{N}}$ & $\begin{array}{l}\stackrel{ }{+} \\
\frac{-}{2}\end{array}$ & $\begin{array}{l}\mp \\
\mp \\
\stackrel{\infty}{\infty} \\
\stackrel{\infty}{\longrightarrow}\end{array}$ & $\begin{array}{l}\stackrel{\sim}{-} \\
\stackrel{\infty}{m}\end{array}$ \\
\hline 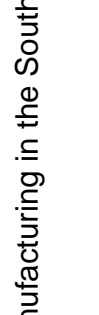 & 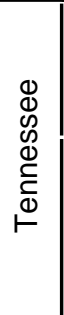 & 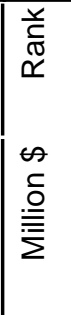 & 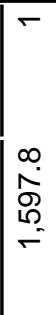 & $\begin{array}{l}\circ \\
\stackrel{\infty}{\mathfrak{D}}\end{array}$ & $\frac{0}{\stackrel{\circ}{L}}$ & $\begin{array}{l}\infty \\
\stackrel{0}{0} \\
\end{array}$ & $\begin{array}{l}0 \\
0 \\
0 \\
0\end{array}$ & $\frac{m}{N}$ & $\begin{array}{l}0 \\
\stackrel{\rho}{R}\end{array}$ & $\stackrel{+}{\curvearrowright}$ & ஓ্் & 芦 & $\begin{array}{l}\bar{F} \\
\bar{i}\end{array}$ & $\begin{array}{l}\stackrel{\sim}{~} \\
\dot{q}\end{array}$ \\
\hline 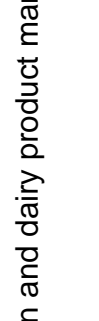 & 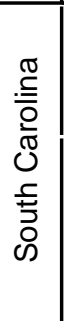 & 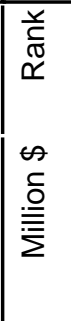 & $\frac{\infty}{\infty}$ & $\begin{array}{l}\mathscr{\varphi} \\
\stackrel{g}{q}\end{array}$ & $\stackrel{\mathscr{N}}{\sim}$ & 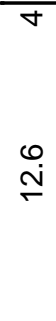 & 苍 & 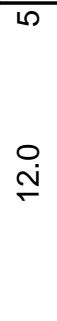 & $\begin{array}{l}\text { Oे } \\
\stackrel{0}{\circ}\end{array}$ & $\stackrel{\leftrightarrow}{\sigma}$ & $\stackrel{\circ}{\mp}$ & $\infty$ & $\stackrel{\infty}{\infty}$ & $\stackrel{\circ}{1}$ \\
\hline 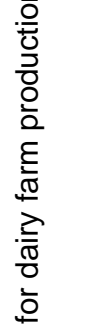 & $\begin{array}{l}\frac{\pi}{2} \\
\frac{0}{0} \\
0 \\
0\end{array}$ & 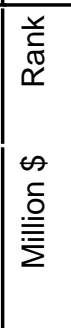 & $\frac{5}{\stackrel{5}{F}}$ & 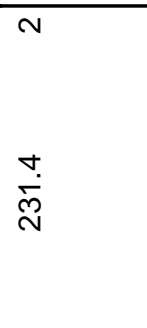 & $\frac{N}{\bar{\sigma}}$ & $\hat{\varphi}$ & $\begin{array}{l}\hat{\infty} \\
\stackrel{\infty}{0}\end{array}$ & $\begin{array}{l}\text { @ } \\
\text { ले }\end{array}$ & $\stackrel{\infty}{\circ}$ & 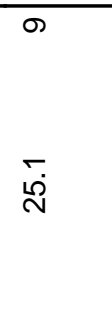 & $\stackrel{\text { N }}{\text { N }}$ & $\begin{array}{l}+\circ \\
\stackrel{\circ}{\sim}\end{array}$ & $\begin{array}{l}\mp \\
\stackrel{m}{N}\end{array}$ & $\begin{array}{l}\stackrel{N}{\simeq} \\
\stackrel{0}{\circ}\end{array}$ \\
\hline 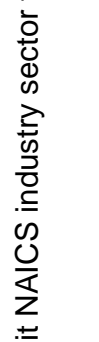 & $\begin{array}{l}\frac{\pi}{0} \\
\frac{0}{0} \\
\frac{0}{4}\end{array}$ & 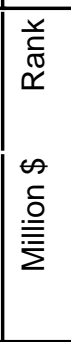 & 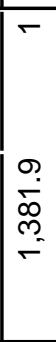 & $\begin{array}{l}\stackrel{n}{\mathscr{P}} \\
\stackrel{9}{y}\end{array}$ & $\begin{array}{l}\ddot{0} \\
\stackrel{\circ}{\circ}\end{array}$ & $\begin{array}{l}\circ \\
0 \\
0\end{array}$ & $\stackrel{\stackrel{\sim}{N}}{\underset{T}{\tau}}$ & $\stackrel{\infty}{\infty} \underset{\infty}{\infty}$ & $\underset{\infty}{\stackrel{S}{\infty}}$ & $\begin{array}{l}\infty \\
\\
0 \\
\infty \\
\infty\end{array}$ & $\frac{\infty}{\infty}$ & $\begin{array}{l}\circ \\
\circ \\
\stackrel{9}{0}\end{array}$ & $\begin{array}{l}\stackrel{N}{\div} \\
\stackrel{9}{\circ}\end{array}$ & $\begin{array}{l}\mp \\
\infty \\
\dot{0}\end{array}$ \\
\hline 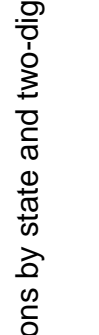 & $\begin{array}{l}\underset{\pi}{\mathbb{T}} \\
\frac{\pi}{0} \\
\frac{\pi}{\pi} \\
\frac{\pi}{<}\end{array}$ & 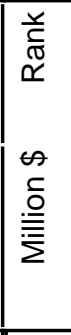 & 菅 & $\begin{array}{l}\infty \\
\dot{q} \\
q\end{array}$ & $\frac{t}{i n}$ & $\hat{\dot{m}}$ & $\begin{array}{l}\stackrel{n}{N} \\
\stackrel{n}{0}\end{array}$ & $\hat{\stackrel{N}{~}}$ & 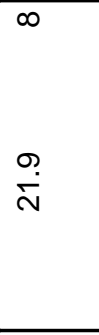 & $\begin{array}{l}0 \\
0 \\
\stackrel{N}{N}\end{array}$ & $\stackrel{\text { N }}{\stackrel{N}{N}}$ & $\begin{array}{l}\mp \\
\mp \\
\infty \\
\infty\end{array}$ & $\begin{array}{l}\stackrel{\circ}{\circ} \\
\stackrel{ }{\circ}\end{array}$ & $\underset{v}{\stackrel{v}{\check{~}}}$ \\
\hline 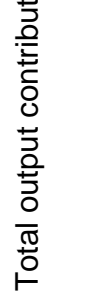 & $\begin{array}{l}0 \\
\frac{0}{5} \\
\vdots \\
\vdots \\
\overline{0} \\
0 \\
\infty\end{array}$ & 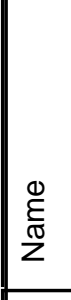 & 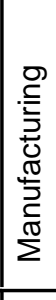 & 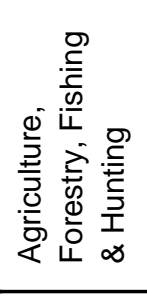 & 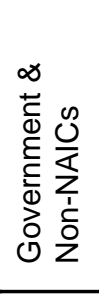 & $\begin{array}{l}\frac{0}{0} \\
\frac{\pi}{2} \\
\stackrel{0}{0} \\
\frac{0}{\pi} \\
0 \\
\frac{0}{0} \\
\sum_{3}^{5}\end{array}$ & 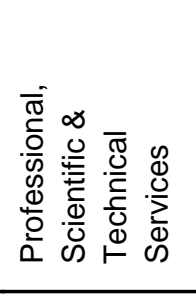 & 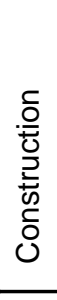 & 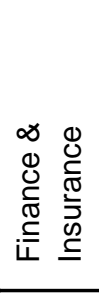 & 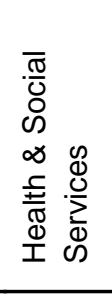 & $\begin{array}{l}\frac{0}{\pi} \\
\stackrel{\pi}{2} \\
\overline{\bar{\pi}} \\
\frac{\pi}{0} \\
\widetilde{0}\end{array}$ & 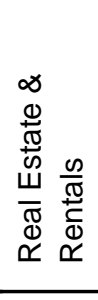 & 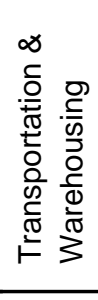 & 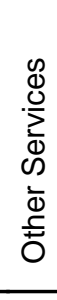 \\
\hline $\begin{array}{l}\frac{\dot{T}}{0} \\
\frac{0}{0} \\
\frac{0}{\sigma} \\
\stackrel{\circ}{\circ}\end{array}$ & 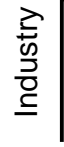 & $\#$ & $\frac{\text { Pூ }}{\frac{1}{m}}$ & $\mp$ & ๙ু & $\stackrel{\sim}{\mathcal{Y}}$ & Lั & $\widetilde{N}$ & กิ & $\widetilde{\mho}$ & 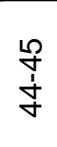 & గొ & 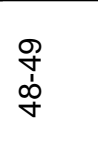 & $\bar{\infty}$ \\
\hline
\end{tabular}




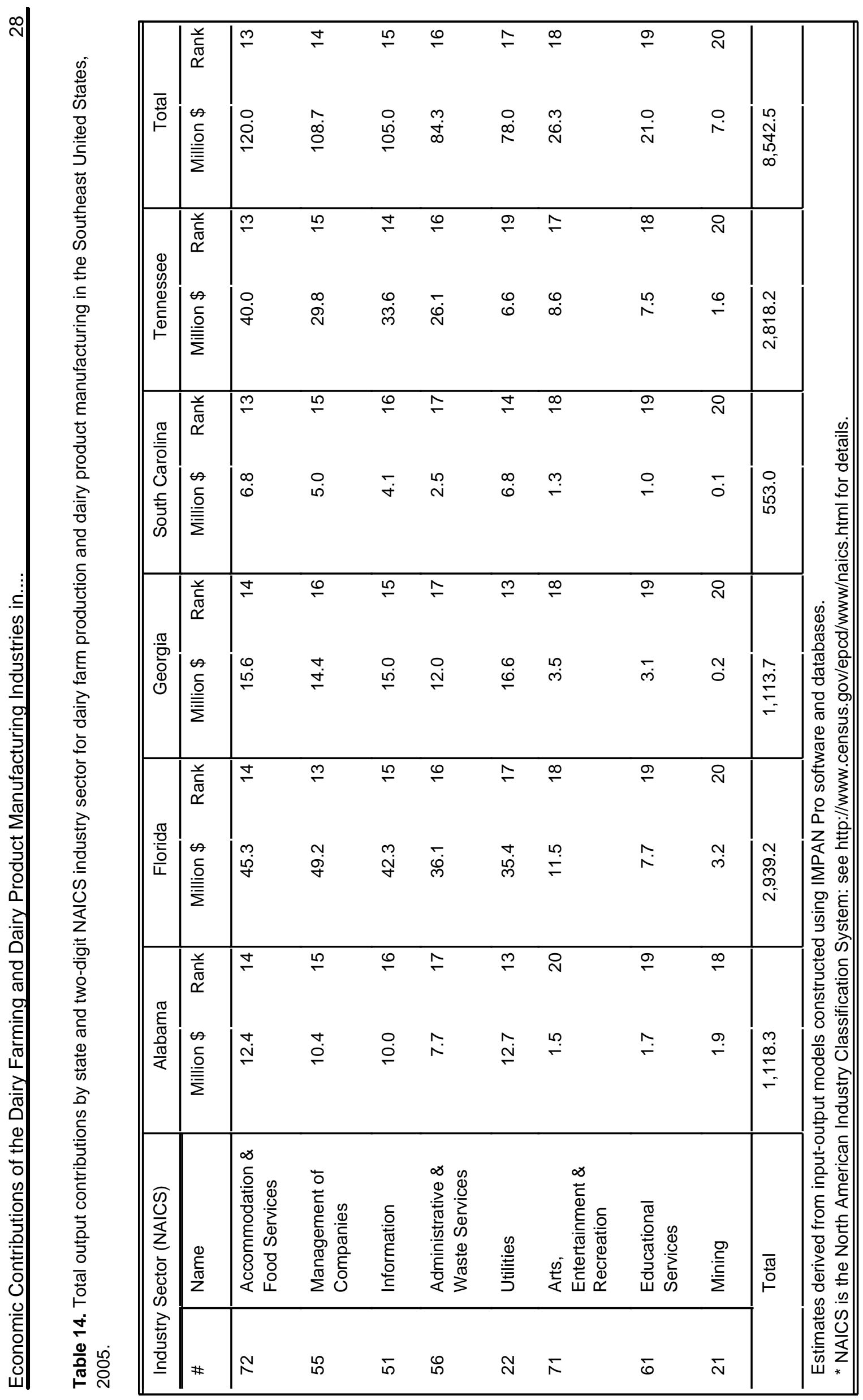




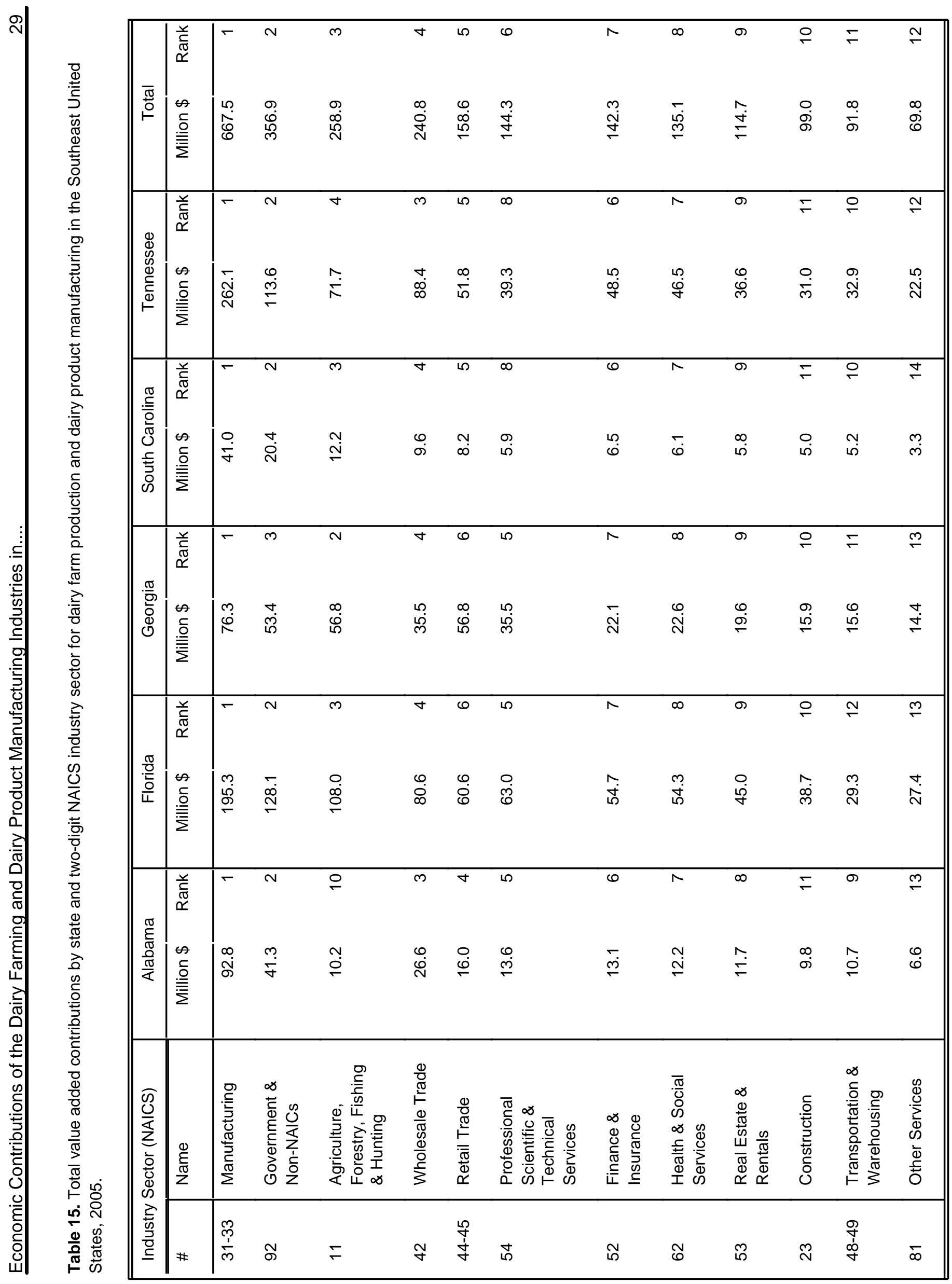




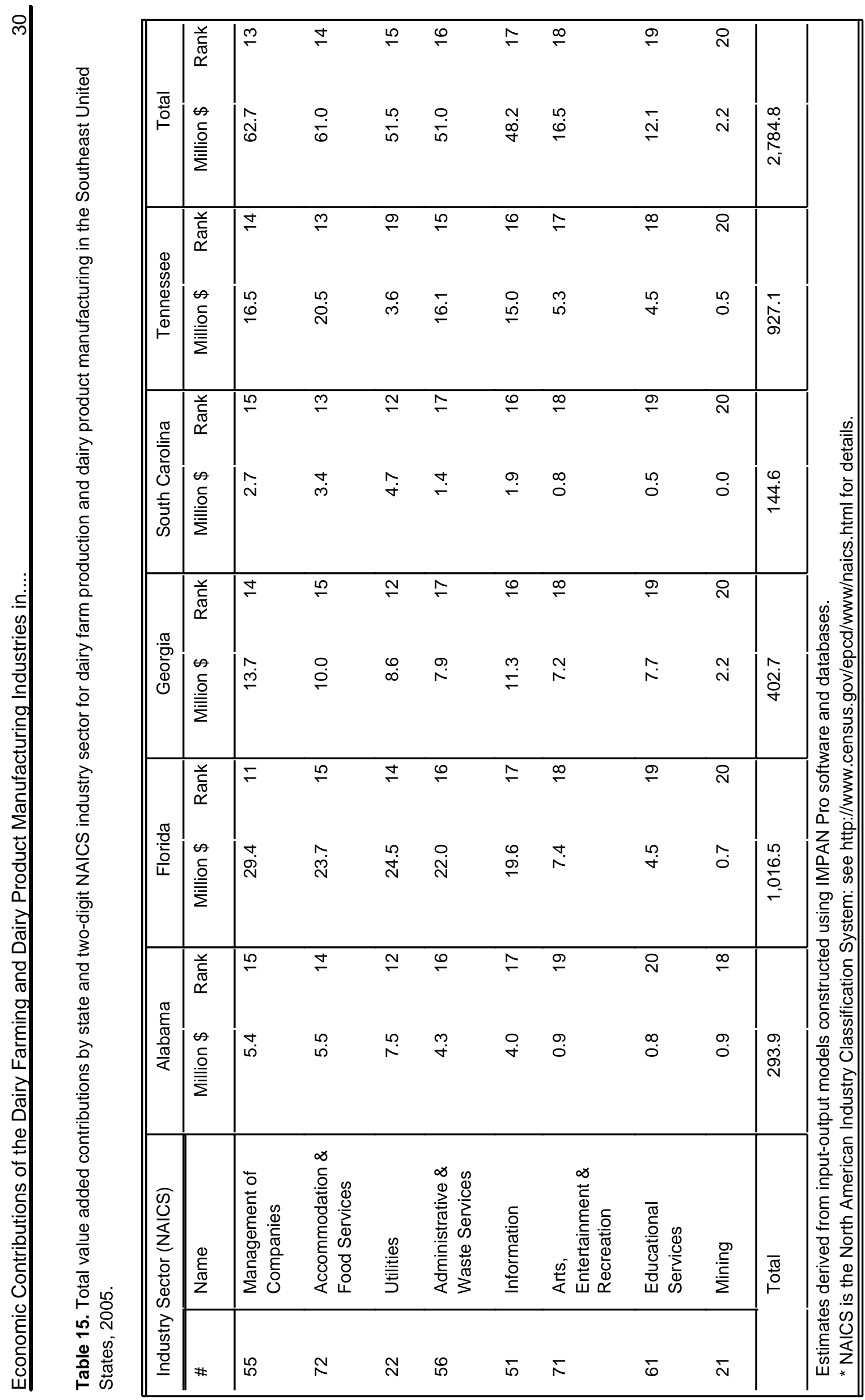




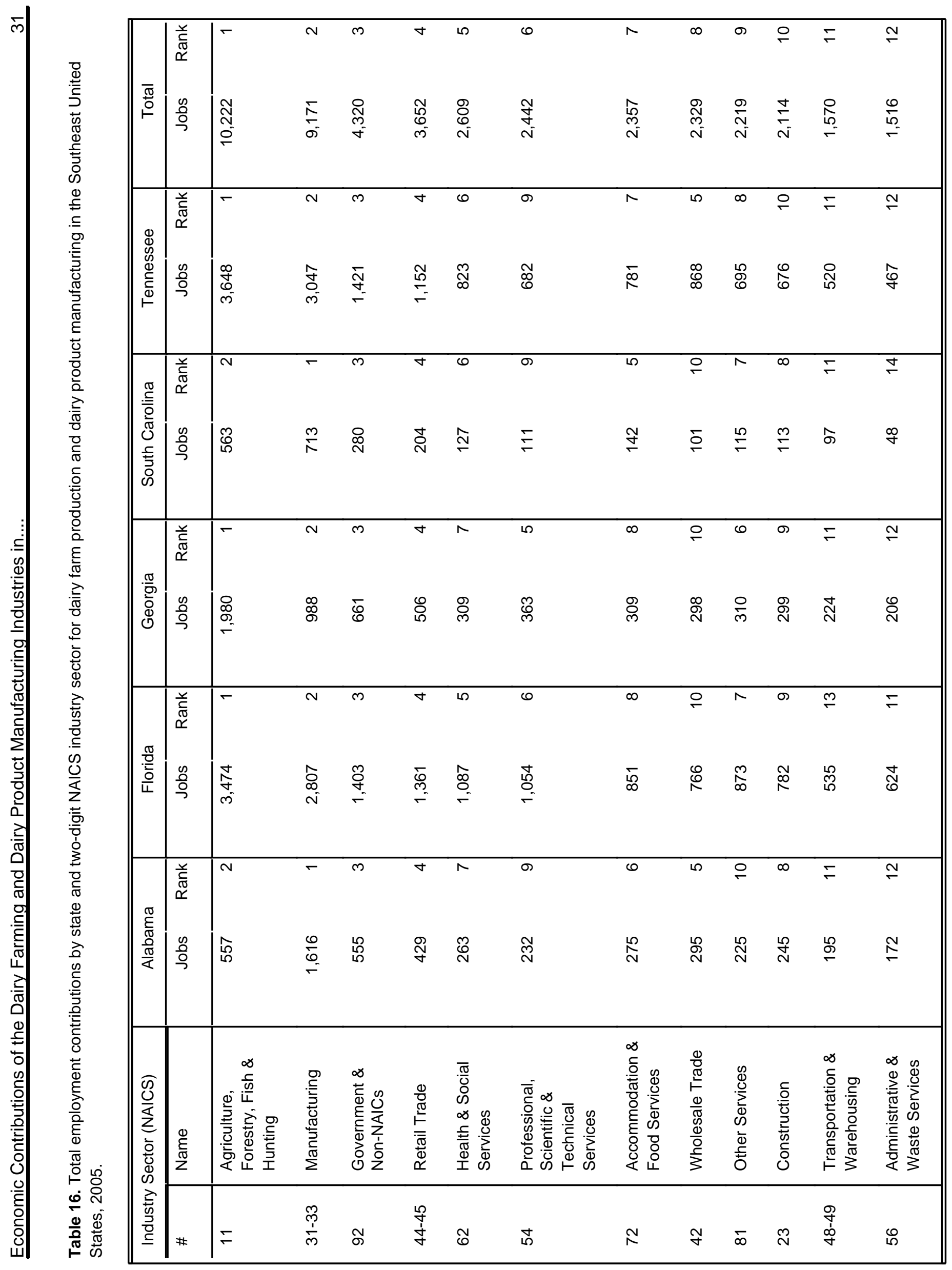




\begin{tabular}{|c|c|c|c|c|c|c|c|c|c|c|c|c|}
\hline 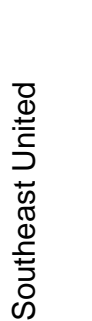 & $\begin{array}{l}\bar{\sigma} \\
\stackrel{0}{\circ}\end{array}$ & 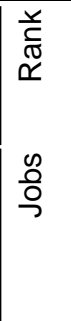 & $\begin{array}{l}\stackrel{m}{-} \\
0 \\
0 \\
0 \\
=\end{array}$ & $\begin{array}{l}\stackrel{+}{-} \\
\text { ஜ্ণ } \\
\stackrel{-}{-}\end{array}$ & $\begin{array}{l}\stackrel{10}{+} \\
\mathbb{0} \\
\mathbb{0}\end{array}$ & $\begin{array}{l}\stackrel{\infty}{ } \\
\stackrel{\infty}{+}\end{array}$ & $\stackrel{-}{\llcorner}$ & $\stackrel{\infty}{\leftarrow}$ & $\stackrel{\circ}{\leftarrow}$ & ฉ & 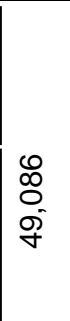 & \\
\hline 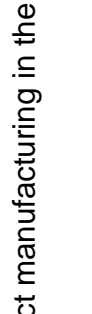 & 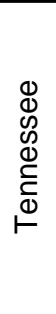 & 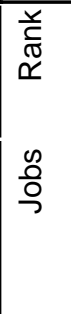 & ‡ & $\begin{array}{l}\stackrel{+}{\square} \\
\stackrel{্}{\infty}\end{array}$ & $\begin{array}{l}\stackrel{n}{\circ} \\
\stackrel{\sim}{\sim}\end{array}$ & $\begin{array}{l}\stackrel{N}{ᄃ} \\
\stackrel{\Omega}{\Omega}\end{array}$ & 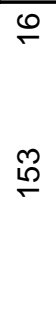 & $\stackrel{\infty}{\leftarrow}$ & $\underset{\tau}{ }$ & 0 & $\begin{array}{l}\stackrel{N}{N} \\
\underset{0}{0}\end{array}$ & \\
\hline 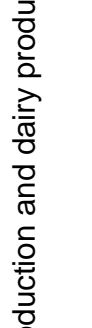 & 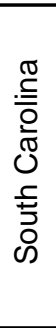 & 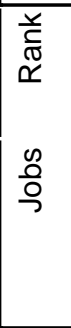 & $\bar{\lambda}$ & $\begin{array}{l}\stackrel{m}{\leftarrow} \\
\text { ถิ }\end{array}$ & ले & $\ddot{0}$ & 尺 & $\stackrel{\wedge}{\digamma}$ & $\stackrel{L}{\leftarrow}$ & 0 & 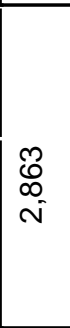 & 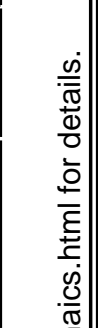 \\
\hline 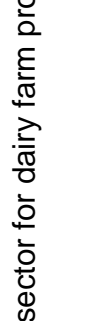 & $\begin{array}{l}\frac{\pi}{\pi} \\
\frac{0}{0} \\
0 \\
0\end{array}$ & 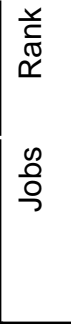 & $\underset{6}{6}$ & $\stackrel{\cong}{\sim}$ & $\mathscr{\infty}$ & $\hat{\emptyset}$ & $\hat{\forall}$ & $\stackrel{\wedge}{\therefore}$ & $\stackrel{\sim}{\sim}$ & - & స్ర్ర & 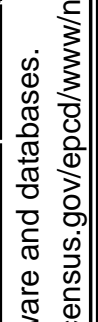 \\
\hline 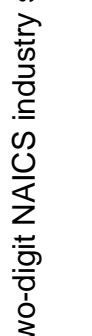 & $\frac{\frac{\pi}{0}}{\frac{ㅇ}{}}$ & 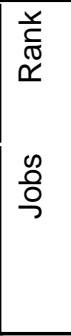 & L & \&্) & $\stackrel{\mathscr{N}}{\text { D }}$ & ळ̆ & $\stackrel{N}{r}$ & 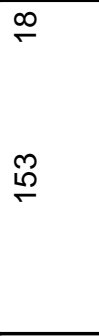 & ( ) & 尺ి & 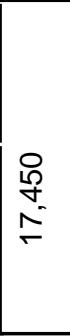 & 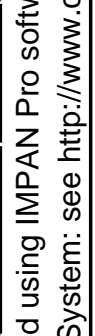 \\
\hline 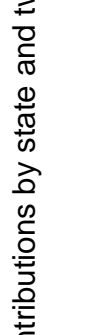 & $\begin{array}{l}\frac{\pi}{\sigma} \\
\frac{\pi}{\pi} \\
\frac{0}{\pi} \\
\frac{\pi}{<}\end{array}$ & 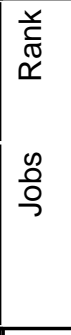 & $\stackrel{\infty}{\stackrel{m}{\sim}}$ & $\begin{array}{l}\stackrel{ \pm}{\leftarrow} \\
\stackrel{N}{\simeq}\end{array}$ & $\stackrel{\circ}{\leftarrow}$ & 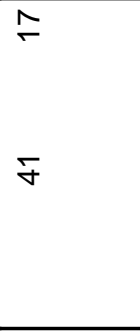 & 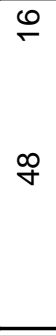 & $\stackrel{\infty}{r}$ & $\stackrel{9}{\leftarrow}$ & 尺 & 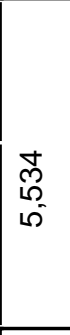 & 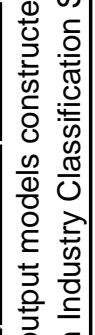 \\
\hline 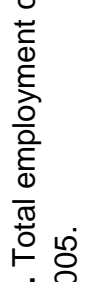 & 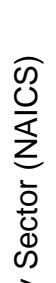 & $\begin{array}{l}\stackrel{\otimes}{E} \\
\frac{\text { I }}{Z}\end{array}$ & 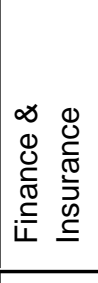 & 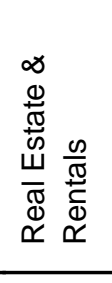 & 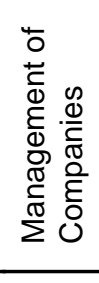 & 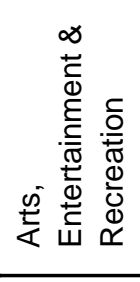 & 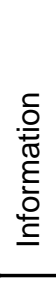 & 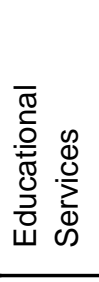 & 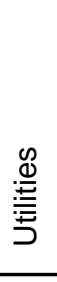 & 胥 & $\begin{array}{l}\overline{\widetilde{\pi}} \\
\stackrel{0}{\circ} \\
\vdash\end{array}$ & 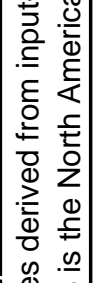 \\
\hline 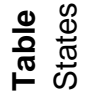 & 흠 & $\#$ & กิ & నొ & น & $\bar{N}$ & $\bar{n}$ & $\bar{\sigma}$ & స & $\bar{\sim}$ & & 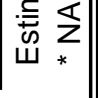 \\
\hline
\end{tabular}

